\title{
PATENTS AND THE Regulatory STATE: RETHINKING THE PATENT BARgain METAPHOR AFTER ELDRED
}

\author{
By Shubba Gbosh ${ }^{t}$
}

\begin{abstract}
The metaphor of the patent bargain-that a patent represents the grant of the right of exclusivity in exchange for the disclosure of a novel invention-is generally accepted in the patent law community. Evidence of the metaphor's persuasiveness and pervasiveness is provided by the U.S. Supreme Court's reliance on the patent quid pro quo as a framing device to address the constitutionality of copyright term extension in $\mathrm{El}$ dred v. Ashcroft. This Article challenges the coherence of the patent bargain metaphor by arguing that the metaphor rests on an outdated notion of the state that is inconsistent with the many regulatory goals of patent law. Thus, the patent law community should replace the quid pro quo metaphor with a regulatory theory of patents that views patent law as regulating primary conduct in the innovation process.

First, I critique the patent bargain metaphor as a broad criticism of social contract theory as applied to patent law. Social contract theory rests on a quaint and pre-modern notion of government that is inconsistent with the realities of the modern regulatory state. Second, social contract theory rests on a misguided reliance on the prisoners' dilemma as a characterization of the private ordering problems that patent law is designed to address. The prisoners' dilemma ignores the role of reciprocity and trust in the innovation process. This Article presents the assurance game as an alternative representative of the problem of private ordering and basis for patent law. The assurance game expressly incorporates reciprocity and trust into an evolutionary view of the prisoners' dilemma and supports the view that, much like securities law, patent law is a regulatory system designed to promote reciprocity and trust. Third, I compare assurance game theory to four existing theories of patent law: prospect-
\end{abstract}

(C) 2004 Shubha Ghosh

$\dagger$ B.A., Amherst College; Ph.D., University of Michigan; J.D., Stanford Law School; Professor of Law, University at Buffalo, SUNY, Law School; Visiting Professor, SMU Dedman School of Law. The author would like to thank Christina Bohannon, Michael Meurer, Adam Mosoff, Joshua Sarnoff, and R. Polk Wagner for comments on an earlier draft of the Article and on a presentation at the Fourth Annual Intellectual Property Scholars Conference at Depaul College of Law, and Dean John Attanasio of SMU and Dean Nils Olsen of The University at Buffalo for generous research support. 
ing theory, information costs theory, business asset theory, and industry regulation theory. Fourth, I address three salient patent reform proposals, limitations on patentable subject matter, the National Academy of Sciences reform proposals, and the Federal Trade Commission reform proposals within the frame of the assurance game. Although this Article critiques many existing patent reform proposals, such as the narrowing of subject matter in consideration of competitive concerns and the loosening of the presumption of validity, the Article agrees with the spirit of the proposals as examples of the regulatory theory of patent law in practice. These applications demonstrate the power of thinking of patent law in terms of the assurance game and represent the initial steps towards developing a regulatory theory of patent law.

\section{TABLE OF CONTENTS}

I. INTRODUCTION: ELDRED ON PATENTS AND SOCIAL CONTRACT THEORY 1316

II. PATENTS AS MARKeT REgUlation AND SCIENCE POLICY

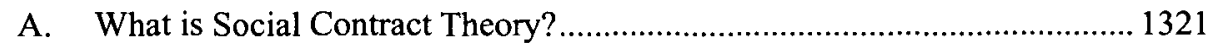

1. Social Contract Theory as Politics...................................................... 1322

2. Social Contract Theory as Economics ........................................... 1325

B. Social Contract Theory and Patent Law ............................................... 1328

1. Economics of Patent Law: The Prisoners' Dilemma Versus the Assurance Game.

2. The Administration of Patent Law and Policy .................................. 1339

3. Patent Law and Inventorship ......................................................... 1345

C. Patent Law, Private Orderings, and the Well-Regulated Marketplace ........ 1349

III. The Assurance Game AND the MANy Faces of PATENT LAW ........................1353

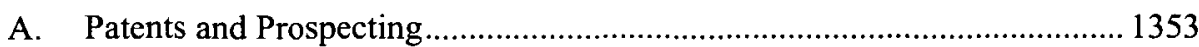

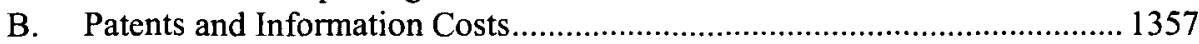

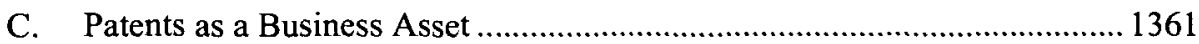

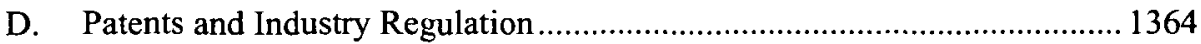

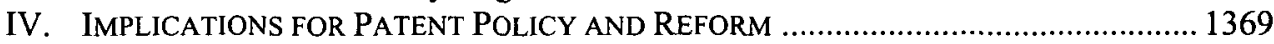

A. Patentable Subject Matter.................................................................. 1370

B. The NAS Study as a Model for Regulatory Patent Law: A Critical

Commentary of Agencies and Courts..................................................... 1375

C. Patent Law and Competition Policy ......................................................... 1382

V. AFTER THE PATENT BARGAIN METAPHOR: LESSONS FROM ELDRED .................... 1387

\section{INTRODUCTION: ELDRED ON PATENTS AND SOCIAL CONTRACT THEORY}

Patents are commonly understood as a hypothetical contract between the inventor and the government resulting in a quid pro quo of innovation for exclusivity. This view of patents affects the interpretation of other areas of intellectual property law, such as copyright law. For example, in 
Eldred v. Ashcroft ${ }^{1}$ the U.S. Supreme Court rejected the analogy between patent and copyright by concluding that "patents and copyrights do not entail the same exchange, and that our references to a quid pro quo typically appear in the patent context." ${ }^{, 2}$ According to the Court, disclosure of an invention is "the price paid for the exclusivity secured" by patent while, in contrast, no disclosure is required for a copyright, which is seemingly granted without any return promise. ${ }^{3}$ The fluidity with which the Court cast the terms of the hypothetical contract illustrates Professor Ed Rubin's criticism that social contract theory leads to "overinterpretation." The Court, or any other user of social contract theory, "by varying the terms of the imaginary narrative ... can prove virtually anything." I argue that social contract theory is indeterminate and inadequate to understand patent law (as well as intellectual property more broadly). I critically assess social contract theory, particularly the notion that a body of law is justified by an exchange between the state and the affected party. I propose that patent law should be viewed as a form of regulation integrated into other activities of the modern regulatory state.

The move towards treating patent law as a system of regulation parallels the evolution of legal thinking in other areas. Professors Paul M. Schwartz and William Michael Treanor, in their critique of the petitioner's arguments in Eldred v. Ashcroft, argued that, in many areas of the law, constitutional thinking goes through three stages: “(1) a legislative response to economic change, (2) an activist judicial review of the legislative response, and (3) a judicial retreat." to a greater deference to legislation and regulation. Although I disagree with the authors' characterization of Eldred, I agree with their view of how legal regimes, whether property or corporate law, evolve towards regulation. Their view corresponds to why some scholars have called for a "New Deal" for intellectual property.

An overlooked, but relevant, historical parallel to such a view of patent law exists in corporate law. For example, the Proprietors of Charles River

1. 537 U.S. 186 (2003).

2. Id. at 216 .

3. Id.

4. Ed Rubin, After Camelot, Chapter Five, From Legitimacy to Compliance 9 (2003) (unpublished manuscript on file with author).

5. Id. at 10 .

6. Paul M. Schwartz \& William Michael Treanor, Eldred and Lochner: Copyright Term Extension and Intellectual Property as Constitutional Property, 112 YALE L.J. 2331, 2335 (2003).

7. See, e.g., Pamela Samuelson, Toward a "New Deal" for Copyright in the Information Age, 100 MiCH. L. REV. 1488, 1491-95 (2002). 
Bridge v. Proprietors of Warren Bridge opinion concerned a state charter granted to Charles River Bridge Corp. to create and to maintain a bridge in Boston, Massachusetts. ${ }^{8}$ The state allegedly breached the charter by permitting the Warren Bridge Co. to build a competing, toll-free bridge. Justice Taney, writing for the majority, held that the grant of the charter to the Warren Bridge Co. did not violate the contract impairment clause of the Constitution because the Charles River Bridge charter did not prohibit the grant of a second charter. ${ }^{9}$ Were the first charter strictly enforced, he stated, "we shall be ... obliged to stand still until the claims of the old turnpike corporation shall be satisfied, and they shall consent to permit these States to avail themselves of the lights of modern science." 10 The charter, rather than being a contract creating vested rights (as Justice Story contended in his dissent), ${ }^{11}$ was an instrument for economic growth and should be interpreted accordingly.

Charles River Bridge marked a watershed in corporate law by transforming the charter from a contract with the state to a legal instrument that regulates and orders the marketplace. ${ }^{12}$ The case was a beacon for the incorporation movement in the Nineteenth Century that democratized the process of corporate formation and unleashed the energies of competition. ${ }^{13}$ This Article advocates a similar move for the conception of patents. Just as the legal status of corporate charters shifted from contract to a mechanism for private ordering, so too should we move from a view of patents as contracts to a view of patent law as a mechanism for private ordering.

I develop this central argument by defining my meaning of civil society and delineating how patents work as a legal instrument of regulation. I critique the contractual view of patent law, demonstrating that the bargain theory provides a misguided foundation for patent law. In place of the bargain theory, I propose a theory that is based on patent law's role in creating a well-ordered marketplace that allows the flourishing of civil soci-

8. 36 U.S. (11 Pet.) 420 (1837).

9. Id at 537,549 ; see HERBERT HOVENKAMP, ENTERPRISE AND AMERICAN LAW 1836-1937, at 110-14 (1991); Schwartz \& Treanor, supra note 6, at 2397.

10. 36 U.S. (11 Pet.) at 442.

11. Id. at 646-47 (Story, J., dissenting).

12. See HovenKAMP, supra note 9, at 114; see also Robert Merges, Who Owns the Charles River Bridge?: Intellectual Property and Competition in the Software Industry 12 (Mar. 6, 2000) (evoking Charles River Bridge opinion as victory for competition over vested property rights), available at $\mathrm{http}: / /$ papers.ssrn.com/sol3/papers.cfm?abstract_id= 08089.

13. See HovenKAMP, supra note 9 , at 17-35. 
ety. ${ }^{14}$ Part II explains social contract theory in detail and then critiques it as a theory of patent law. The bargain theory of contract assumes that the problem of patent law can be described by the prisoners' dilemma even though the problem is more appropriately characterized by what game theorists call an assurance game. Part III compares my regulatory theory of patent law with four established theories of patent law: (1) prospecting theory; (2) information cost theory; (3) business asset theory; and (4) industry regulation theory. Part IV applies the regulatory theory to three specific areas of patent reform: limitations on patentable subject matter based on morality and public safety, the 2004 National Academy of Sciences (NAS) report recommending changes to patent prosecution, ${ }^{15}$ and the 2003 Federal Trade Commission (FTC) report reconciling patent law with antitrust and unfair competition law. ${ }^{16}$ Each of these areas implicates patents as a means of regulation and illustrates my regulatory theory of patents. Finally, Part V concludes by reflecting on what Eldred reveals about the inadequacies of the patent bargain metaphor.

\section{PATENTS AS MARKET REGULATION AND SCIENCE POLICY}

The conception of patent law as social contract has a long pedigree and a confusing history. Since 1829 , the term "quid pro quo" has been used in over one hundred patent opinions, six of them by the U.S. Supreme Court. The 1829 decision Pennock et al. v. Dialogue contains the earliest discussion of the patent grant as a quid pro quo in the United States. ${ }^{17}$ In it, Justice Story wrote:

[I] $\mathrm{f}$ the public were already in possession and common use of an invention fairly and without fraud, there might be sound reason for presuming, that the legislature did not intend to grant an ex-

14. For a historical discussion of the concept of the ordered marketplace, see JAMES WILLARD HURST, LAW AND THE CONDITIONS OF FREEDOM IN THE NINETEENTH-CENTURY UNITED STATES 40-51 (1956); CHARLES SEllers, THE MARKET REVOLUTION: JACKSONIAN AMERICA 1815-1846, at 28-33 (1991). For a discussion of private orderings and the marketplace in the context of intellectual property, see Mark A. Lemley, Ex Ante Versus Ex Post Justifications for Intellectual Property, 71 U. Chi. L. Rev. 129, 149 (2004).

15. NAT'L RESEARCH COUNCIL, NAT'L ACAD. Of SCIS., A PATENT SySTEM FOR THE 21 ST CENTURY (Stephen A. Merrill ed al. eds., 2004) [hereinafter NAS STUDY], available at http://www.nap.edu/books/0309089107/html.

16. Fed. Trade Comm'N, To Promote Innovation: The Proper Balance of COMPETITION IN PATENT LAW AND POLICY (2003) [hereinafter FTC REPORT], available at http://www.ftc.gov/os/2003/10/innovationrpt.pdf.

17. 27 U.S. (2 Pet.) 1 (1829). 
clusive right to any one to monopolize that which was already common. There would be no quid pro quo-no price for the exclusive right or monopoly conferred upon the inventor for fourteen years. ${ }^{18}$

The "price" that Justice Story failed to find can be understood in two ways. A grant of exclusivity may require the exaction of creativity from the inventor. Awarding a patent to an invention that is publicly used would exact no toll from an inventor who simply has taken what is already known. ${ }^{19}$ This interpretation would support the novelty requirement of patent law. ${ }^{20}$ Alternatively, Justice Story's "price" could refer to the exclusivity that is exchanged for disclosure of the invention; with a publicly known invention, the patentee would have given up nothing because he has told us nothing. ${ }^{21}$

These two characterizations of "price" resonate in subsequent Supreme Court case law. In Universal Oil Products Co. v. Globe Oil \& Refining Co., which marks the Supreme Court's second use of quid pro quo, the Court employed the second interpretation. ${ }^{22}$ The "quid pro quo" is viewed as a "disclosure ... in sufficient detail to enable one skilled in the art to practice the invention" upon patent expiration. ${ }^{23}$ In 1966, in Brenner $v$. Manson, the Court redefined the quid pro quo as "the benefit derived by the public from an invention with substantial utility." ${ }^{24}$ However, in 1974, the Court returned to the interpretation of Universal Oil in Kewanee Oil Co. v. Bicron Corp., a decision reconciling the promotion of disclosure through patent law with the promotion of secrecy through trade secret law. ${ }^{25}$ In the 1989 Bonito Boats decision, the Court adopted a broad view of the price, described as "substantial creative effort" exacted from the patentee in exchange for a limited monopoly. ${ }^{26}$ The Court reverted to a narrower definition in J.E.M. Ag Supply, Inc. v. Pioneer Hi-Bred International, Inc., a 2001 decision that justified the expansion of patent law to

18. Id. at 23 .

19. See Note, Prior Art in the Patent Law, 73 HARv. L. REV. 369, 374-75 (1959).

20. See 35 U.S.C. $\S 102(2000)$.

21. See id. $\S 112$.

22. 322 U.S. 471 (1944).

23. Id. at 484 .

24. 383 U.S. 519,534 (1966).

25. 416 U.S. 470,485 (1974).

26. Bonito Boats, Inc. v. Thunder Craft Boats, Inc., 489 U.S. 141, 161 (1989). The Court called it the "congressionally mandated price for disclosure" paid by the public. Id. at 152 . 
cover plants because of the quid pro quo of disclosure as enunciated in Kewanee. ${ }^{27}$

Two points emerge from the Supreme Court cases that expressly use the quid pro quo language. First, the bargain analogy is a tool of statutory interpretation that permits the Court to give substance to the patent statute. In Pennock, the bargain metaphor aids in understanding the novelty requirement. In Universal Oil and Brenner, the bargain metaphor acts as an interpretive aid for the written description and utility requirements. In other cases, the metaphor helps develop foundational principles that guide the Court in determining the contours of preemption, as in Kewanee and in Bonito Boats, or in gauging the contours of patentable subject matter, as in J.E.M. As I discuss in greater detail in Part IV, there are several seminal cases (Graham v. John Deere Co. ${ }^{28}$ and Diamond v. Chakrabarty ${ }^{29}$ ) where the Court did not appeal to the bargain example. The cases in which the bargain metaphor is silent suggest the emptiness of the metaphor. Once the Court views patents as a bargain between the inventor and the public, the Court can use the term quid pro quo to impose burdens or obligations on the inventor as it sees fit. Even though, except for J.E.M. and Kewanee, the cases invoking the bargain are ones in which the patentee loses, the malleability of the implicit contract suggests that almost any outcome is possible with the bargain metaphor.

In the following sections, I articulate a critical examination of social contract theory as applied to patent law. Section A provides a brief discussion of social contract theory. Section B analyzes how social contract theory provides a basis for patent law and argues this theory fails on three levels because it poorly describes the economics of patents, patent legislation and administration, and patent practice. Section $\mathrm{C}$ constructs an alternative to the social contract theory that responds to my criticisms and recognizes patent law as a basis for a well-regulated marketplace.

\section{A. What is Social Contract Theory?}

Social contract theory recognizes that government should be based on the consent of the governed rather than on the natural right of the ruler. ${ }^{30}$

27. 534 U.S. $124,142(2001)$.

28. 383 U.S. 1 (1966).

29. 447 U.S. 303 (1980).

30. See David Boucher \& Paul Kelly, The Social Contract and Its Critics: An Overview, in The Social CONTRACT FROM HobBes to RAWLS 1, 13-16 (David Boucher \& Paul Kelly eds., 1994) [hereinafter THE SOCIAL CONTRACT]; Joshua Foa Dienstag, Between History and Nature: Social Contract Theory in Locke and the Founders, $58 \mathrm{~J}$. POLS. 985, 992-95 (1996). 
In subsection 1, I outline how social contract theory provides a foundation for democratic institutions and representative government. ${ }^{31}$ In subsection 2 , I outline how social contract theory provides a means to justify economic regulation that corrects market failures or redistributes resources. ${ }^{32}$ As both political and economic theory, social contract theory has a rich pedigree that is beyond the scope of this Article. My goal is to present a definition that explains how social contract theory has been applied to patent law and why such an application is misguided.

\section{Social Contract Theory as Politics}

As a political theory, social contract theory takes many forms depending upon how the contract is entered and how the terms are construed. Traditionally, the contract arises among human beings existing in a state of nature, interacting according to the laws of natural science. ${ }^{33}$ The state of nature can be described in different ways, including as a world in which life is solitary, nasty, brutish and short, or one in which humans exist in a communal arrangement. ${ }^{34}$ The social contract entails a movement from the state of nature to the creation of organized society, regulated by social rules and conventions which can take many forms. ${ }^{35}$ Parties enter the contract by consent and, as a result, the state forms in a manner that serves to protect the interests of its members, either in a minimalist, protectionist way or in a paternalistic way. Therefore, social contract as a political theory rests on two principles: consent and promise. ${ }^{36}$ Consent limits the powers of the state, ${ }^{37}$ while promise binds one citizen to another and the state to its citizens. ${ }^{38}$ In the next few paragraphs, I discuss how the two principles of consent and promise have been applied to understand intellectual property and why this application is misguided.

With this simplified description in mind, let me focus on John Locke, the social contract theorist who has had the greatest influence on our cur-

31. See Paul Kelly, Justifying 'Justice': Contractarianism, Communitarianism, and the Foundations of Contemporary Liberalism, in THE SOCIAL CONTRACT, supra note 30, at 229, 241-43.

32. See Ken Binmore, Bargaining and Morality, in RATIONALITY, JUSTICE AND THE Social ConTract 131, 136-40 (David Gauthier \& Robert Sugden eds., 1993).

33. See Dienstag, supra note 30 , at 993-94.

34. Murray Forsyth, Hobbes' Contractarianism: A Comparative Analysis, in THE SOCIAL CONTRACT, supra note 30, at 35, 39-43 (comparing Hobbes, Locke, and communitarian theorists); see Kelly, supra note 31, at 230-31.

35. See Dienstag, supra note 30, at 997-99.

36. See Rubin, supra note 4 , at 13-15.

37. Id. at 15 .

38. Id. 
rent understanding of property. ${ }^{39}$ Locke viewed property as ownership arising from the application of human labor to nature. ${ }^{40}$ Humans acquire property through work, but this property right is not based on natural law or morality. Property is obtained subject to the Lockean proviso that the commons is left "enough and as good" as before the individual appropriation. ${ }^{41}$ The Lockean proviso can be understood in terms of consent and promise. Every citizen consents to this notion of property by the creation of the state. Furthermore, each citizen promises to leave the commons as "enough and as good" as before their acquisition of property through application of labor. ${ }^{42}$ Thus, a Lockean basis for intellectual property incorporates these terms of the social contract. ${ }^{43}$ Through individual effort applied to the resources of nature-ideas, natural phenomena, laws of nature, and abstract conceptions ${ }^{44}$ - citizens transform these natural resources into creations and inventions, which are the basis for intellectual property rights. Yet these rights are granted subject to the demands of the commons and are delimited in law by such statutory doctrines as protectible subject matter and fair use in copyright and experimental use and repair in patent. $^{45}$

39. See, e.g., Wendy J. Gordon, A Property Right in Self-Expression: Equality and Individualism in the Natural Law of Intellectual Property, 102 YALE L.J. 1533, 1541-45 (1993); Justin Hughes, The Philosophy of Intellectual Property, 77 GEO. L.J. 287, 300-15 (1988).

40. See Hughes, supra note 39 , at 302-03.

41. See, e.g., Anupam Chander, The New, New Property, 81 TEX. L. REV. 715, 744 (2003).

42. John Locke, Treatise of Civil Government and a LeTter Concerning TOLERATION 22 (Charles L. Sherman ed., 1937) (1689).

43. See Hughes, supra note 39 , at 309-11.

44. See Adam L. Mossoff, Rethinking the Development of Patents: An Intellectual History, 1550-1800, 52 HASTINGS L.J. 1255, 1308-09 (2001).

45. For a discussion of these and other limits, see Dan L. Burk \& Mark A. Lemley, Policy Levers in Patent Law, 89 VA. L. ReV. 1576, 1630-60 (2004); Glynn S. Lunney Jr., Patent Law, the Federal Circuit, and the Supreme Court: A Quiet Revolution, 11 SUP. CT. ECON. REV. 1, 7-11 (2004) (describing shifts in doctrines limiting patents). 
As illustration of the limits of social contract theory, ${ }^{46}$ particularly the malleability of the notions of consent and promise, consider a social contract theory of intellectual property based on the thoughts of Thomas Hobbes rather than that of John Locke. No scholar has expressly developed a Hobbesian theory of patent or of copyright, but as a challenge to social contract theory, it may be useful to imagine what such a theory would look like. ${ }^{47}$ For Hobbes, humans created the leviathan-the sovereign state-to protect themselves from each other in the state of nature. ${ }^{48}$ Without the leviathan, the state of nature was not an idyllic paradise but a condition of savagery and brutality. In the state of nature, to the extent that any creative activity occurred, the objects of creation would be cannibalized, thoughtlessly copied, adapted, distributed, and performed or used, sold, offered to sell, and made by others. Thus, intellectual property law under the leviathan would protect individuals from this state of nature by making them absolute, immutable, bountiful, and unlimited. Humans would consent to these terms if they were enforced equally for all creations, and each author and inventor would promise to all others to abide by this form of the intellectual property social contract.

There is, of course, no reason to choose one form of the social contract over the other within the terms of social contract theory alone. Both the Lockean and the Hobbesian theories rest on consent and promise, but each presents a very different view of intellectual property law. Correspond-

46. The Hegelian view of intellectual property is often contrasted with the Lockean theory. See Hughes, supra note 39, at 330-39. This contrast is important for the discussion here because Hegel was a strong critic of social contract theory. See Boucher \& Kelly, supra note 30 , at 23-26. For Hegel, the state did not arise from the consent of the governed as an embodiment of the promises among its members. Id. at 24-25. Property, according to Hegel, was an integral part of human personality, necessary for flourishing in civil society. See GeORG WILhelm Friedrich Hegel, Philosophy of Right 37-41 (T.M. Knox trans., 1965); see also Margaret Jane Radin, Property and Personhood, 34 STAN. L. REV. 957, 976-78 (1982). The personality view of property has served as the justification for a moral rights theory of copyright. See Stewart E. Sterk, Rhetoric and Reality in Copyright Law, 94 MiCH. L. REV. 1197, 1243-45 (1996). Tellingly, a Hegelian theory of patent is lacking and not fully developed among scholars, evidence of patent law's closer connection to social contract theory. See, e.g., Molly Holman \& Stephen R. Munzer, Intellectual Property Rights in Genes and Gene Fragments: A Registration Solution for Expressed Sequence Tags, 85 IOWA L. REV. 735, 836 n.273 (2000) (pointing out that Hegel discussed copyright but not patents).

47. While intellectual property and other scholars have written about Hobbes and possessive individualism, there seems to be very little connecting Hobbes's philosophy with either copyright or patent. See David Nimmer, Copyright in the Dead Sea Scrolls: Authorship and Originality, 38 Hous. L. REV. 1, 9 (2001) (commenting on absence of any discussion of copyright in Hobbes' work except for reference to "writers").

48. See Forsyth, supra note 34 , at 43-48. 
ingly, social contract theory offers little guidance as a theory of patent law, particularly in political terms. As Ed Rubin has pointed out, social contract theory rests on a quaint, even medieval, notion of promise keeping as an adequate basis for social organization. ${ }^{49}$ As I argue more fully below, we should consider patent law best as a branch of economic regulation that overlaps with administrative law. Therefore, we need a theory that encompasses more than the fungible notions of consent and promise. Traditional social contract theorists had no conception of the modern administrative state or of patent law ${ }^{50}$ and, as the next section shows, no conception of the workings of the marketplace.

\section{Social Contract Theory as Economics}

Even though social contract theory fails as a political justification for patent law, advocates of social contract theory may defend its usefulness as an economic justification. After all, if patent law is a form of economic regulation and contracts are at the heart of economic relationships, then perhaps patents can be understood as contracts. Ultimately, however, social contract theory as an economic concept is equally inadequate because of the manner in which social contract theory describes behavior and institutions.

The key insight of contemporary economics is the recognition of selfinterest as the basis for human action and organized human activity. Albert Hirschman, in his documentary history of the development of the concept of self-interest in Western political and social thought, explains that control of "inconstancy," the tendency of humans to act out of passion in an unpredictable and capricious manner, was of central concern to social contract theorists. ${ }^{51}$ Locke, for example, thought of the social contract as a way to limit the exercise of arbitrary power and to free men from the "Arbitrary Will" of another. ${ }^{52}$ Although Locke did not explore how the appeal to self-interest could limit power and will, modern social contractarians do recognize its importance in framing the social contract. ${ }^{53}$

49. See Rubin, supra note 4 , at 12-14.

50. Id at $16-18$.

51. Albert O. Hirschman, The Passions and the Interests: Political ArguMENTS FOR CAPITALISM BEFORE ITS TRIUMPH 53 (1977).

52. Id. at 53-54.

53. See, e.g., David Gauthier, The Social Contract as Ideology, 6 PHIL. \& PUB. AFF. $130,134-35$ (1977) (discussing Locke's supposition that social contract is among landed proprietors seeking to protect their property). 
The works of John Rawls ${ }^{54}$ and John Harsanyi ${ }^{55}$ illustrate this modern approach to the economic theory of social contracts. Although Rawls is not an economist ${ }^{56}$ and Harsanyi is often characterized as a utilitarian, rather than as a contractarian, ${ }^{57}$ their ideas are essential to and often cited in the literature on social contract and economics. ${ }^{58}$ Rawls's "veil of ignorance" thought experiment and his famous difference principle serve as workhorses in arguments supporting economic and social regulation specifically and notions of justice and fairness generally. ${ }^{59}$ Furthermore, Harsanyi's thought experiment parallels Rawls's (although with a different result) and also provides a basis for social welfare theory. ${ }^{60}$ In addition, Harsanyi's ideas are seminal to the development of game theory, an approach that marries social contract theories with the concept of selfinterest. ${ }^{61}$ I discuss both of these thinkers as representatives of a social contract theory of economics. As is well known, economics is a theory of allocation of resources. ${ }^{62}$ Thus, a social contract theory of economics addresses the methods of allocation to which individuals might agree if they were to bind themselves through social contract. ${ }^{63}$ Put another way, in the face of choosing different ways of allocating resources, for instance the

54. See JoHN RAWLS, A THEORY OF JustiCE (1971).

55. See John Harsanyi, Cardinal Welfare, Individualistic Ethics, and Interpersonal Comparisons of Utility, 63 J. POL. ECON. 309 (1955).

56. See Binmore, supra note 32 , at 132.

57. See RAWLS, supra note 54, at 22-23 n.9 (describing Harsanyi as a utilitarian); Ken Binmore, Social Contract I: Harsanyi and Rawls, 99 ECON. J. 84, 86 (1989) (demonstrating that Harsanyi is not a contractarian but a utilitarian).

58. See Binmore, supra note 57 , at $84-85$ (discussing the economic literature on social contract theory).

59. For definitions of the veil of ignorance and the difference principle, see RAWLS, supra note 54, at 65-73, 118-23. For one indication of the influence of Rawls on legal theory and reform, see William Michael Treanor, Introduction: Symposium on Rawls and the Law, 72 FORDHAM L. REV. 1385 (2004). A few random cites illustrate the appeal of the veil of ignorance to diverse fields of law. See, e.g., Russell Korobkin, Determining Health Care Rights from Behind a Veil of Ignorance, 1998 U. ILL. L. REV. 801; Marc Linder, Tax Glasnost for Millionaires: Peeking Behind the Veil of Ignorance along the Publicity-Privacy Continuum, 18 N.Y.U. REV. L. \& SoC. CHANGE 951 (1990/1991); Adrian Vermeule, Veil of Ignorance Rules in Constitutional Law, 111 YALE L.J. 399 (2001).

60. See Binmore, supra note 57 , at $86-88$.

61. Id. at 90-92 (describing Harsanyi's ideas in relation to game theory).

62. See Donald E. Campbell, Resource Allocation MeChanisms 1-2 (1987) (defining economics as a tool to analyze alternative resource allocation mechanisms).

63. See CAMPBELL, supra note 62, at 14-15; RAWLS, supra note 54, at 239-42. 
choice between equal division of resources or division based on need, what rule would individuals agree to in making this choice $?^{64}$

For Rawls, the answer rested on his famous veil of ignorance experiment. If all individuals had to decide before they knew their lot in life, but were aware of all the possible states of the world and the workings of human nature (such as inconstancy), individuals would want society to allocate resources based on the difference principle: allocating resources to make the worst person in society better off. ${ }^{65}$ The maximin criterion supports a whole host of regulatory and redistributive programs. ${ }^{66}$

Like Rawls, Harsanyi posited a veil of ignorance and a world in which an individual's lot in life is random and unknown before one determines how to decide. ${ }^{67}$ However, in contrast, Harsanyi posited that this lottery should be treated like any other lottery, and applying the techniques of expected utility theory, he derived the criteria of maximizing a weighted sum of the utilities of all the members of society. ${ }^{68}$ Intuitively, the result is simple: if an individual does not know who he will be beyond the veil of ignorance, then there is an equal chance that he could be any member of society. Because an individual could therefore have any set of preferences, the most sensible decision rule would maximize the individual's expected utility, which would be equivalent to the weighted sum of the utilities of all members of society. Therefore, Harsanyi's thought experiment, in contrast with Rawls's, leads to utilitarianism. ${ }^{69}$ Although utilitarian theory is distinct from social contract theory, the form of Harsanyi's argument is contractarian, and his ideas are therefore often discussed in conjunction with those of social contractarians like Rawls. ${ }^{70}$

64. See RAWLS, supra note 54 , at 55-57 (discussing constitutive rules as shaping institutions). Note that the problem is not about choosing a particular allocation of resources but about deciding how to choose.

65. Id. at 152-54 (defining maximin principle).

66. See Rex Martin, Economic Justice: Contractarianism and Rawls's Difference Principle, in THE SOCIAL CONTRACT, supra note 30, at 245, 248-52 (analyzing implications of difference principle for egalitarian distribution).

67. See John C. Harsanyi, Cardinal Utility in Welfare Economics and in the Theory of Risk-Taking, 61 J. POL. ECON. 434, 435 (1953) (describing social welfare functions as "an expression of what sort of society one would prefer if one had an equal chance of being 'put in the place of' any particular member of the society"). Rawls's difference principle is often contrasted with Harsanyi's solution to the social contract for economics.

68. Id. at 315 .

69. See Binmore, supra note 57, at 100 (characterizing Harsanyi as a utilitarian whose ideas can be justified in contractarian terms).

70. See id. at 85-87 (outlining the contractarian elements of Harsanyi's ideas). 
Both Rawls's and Harsanyi's theories illustrate that, although the social contract theory of politics grounds social order in consent and promise, the social contract theory of economics grounds order in an appeal to interest. For both Rawls and Harsanyi, rational individuals acting in their own interest would adopt the respective decisional mechanisms. ${ }^{71}$ Originally, according to both thinkers, individuals exist in a state of uncertainty, aware that once the veil is lifted and social interactions begin, each individual must act in consideration of others' potential actions and reactions depending on social conventions. ${ }^{72}$ However, the two thinkers radically depart in their conclusions. For Rawls, rational individuals preserve themselves ex ante from social adversity ex post by adapting a decisional rule that is protective of the destitute. For Harsanyi, rational individuals realize that they could equally likely have any position in society, rich or poor, strong or weak. As a result, the utilitarian decisional rule, rather than a paternalistic rule, will define the terms of the social contract. Although each thinker reaches his respective rule by appealing to self-interest, the thinkers' assumptions about how individuals understand and seek to protect their interests differ.

The discussion of these theories clarifies this Article's use of social contract theory. My purpose is not to provide an overview of all social contract theories, but rather, to provide a helpful reference point for how I understand social contract theory addresses important questions of politics and economics. In the next section, I present an analysis of the limits of social contract theory as applied to patents. The analysis explains where social contract theory, and hence the patent bargain metaphor, fails and how to fix it.

\section{B. Social Contract Theory and Patent Law}

One can imagine applying the ideas of Rawls and Harsanyi to patent law. As Abraham Lincoln stated, patents "added the fuel of interest to the fire of genius. ${ }^{, 73}$ How, then, should the patent bargain appropriately stoke the flames? An attempt to answer that question illustrates why no one has done so previously. Just as with its application to politics, a social contract theory of economics is too open-ended to solve doctrinal problems of patent law. Of course, social contract theory aims to resolve different prob-

71. Id. at $94-95$.

72. See Boucher \& Kelly, supra note 30 , at 22-23 (describing Harsanyi as a moral contract theory); id. at 25 (describing Rawls and social contract theory).

73. See Abraham Lincoln, Lecture on Discoveries and Inventions, Jacksonville, Ill., Feb. 11, 1859, in LinCOLN: SELECTED SPEeCheS AND WRITING 200, 208 (Library of America ed., 1992) (emphasis in original). 
lems from those inherent in patent doctrines. However, this failure illustrates the problem with engaging patent law through the metaphor of a bargain: metaphorical contracts are ethereal constructs, movable at will, that fail to aid in interpreting and applying patent law.

In attempting to structure social contract theory in accordance with patent law economics, one uncovers other problems with the bargain metaphor. As the contrasting endpoints of Rawls and Harsanyi's thought experiments indicate, application of social contract theory rests on how interests are framed and pursued. Inventors arguably are not as risk averse as Rawls would have us assume. Analytical work by Professor F.M. Scherer suggests that investments in technological and inventive creation are motivated by the long-shot hopes of risk-seeking inventors. ${ }^{74}$ Given the support for risk-seeking behavior, inventors behind the veil of ignorance may actually prefer a strong form of patent law that richly rewards successful inventors rather than a form that seeks to protect unsuccessful inventors who survive through imitation. Furthermore, starting from a state of nature in which inventors expect to work in isolation may be inappropriate. As both Robert Merton ${ }^{75}$ and Rebecca Eisenberg ${ }^{76}$ demonstrate, much inventive activity is collaborative. Cumulative invention and research teams are the norms in many fields, both academic and commercial. $^{77}$ Under these sets of assumptions, applying social contract theory to patent economics requires more knowledge of the type of game inventors play.

In this Section, I explain why social contract theory is a misleading description of patent economics, patent politics, and patent practice. The patent bargain rests on a poor description of the problem that patent law attempts to address. Although the commonly accepted notion is that patent

74. F.M. Scherer, The Innovation Lottery, in EXPANDING THE BOUNDARIES OF INTELLECTUAL PROPERTY: INNOVATION POLICY FOR THE KNOWLEDGE SOCIETY 3, 18-20 (Rochelle Cooper Dreyfuss et al. eds., 2001) [hereinafter EXPANDING THE BOUNDARIES] (noting that inventors seek out the skew aspect of risk, but not the variance aspect).

75. See, e.g., Robert K. Merton, On Social Structure And Science 267-76 (1996) (describing the ethos of science as consisting of universalism, communism, disinterestedness, and organized skepticism).

76. See, e.g., Rebecca S. Eisenberg, Proprietary Rights and the Norms of Science in Biotechnology Research, 97 YALE L.J. 177, 182-95 (1987) (contrasting the traditional view of the ethos and science with the normative framework of patent law).

77. For a discussion of the role of collaboration and cumulative invention in academia, see SHeldon KRIMSKy, SCIENCE IN THE PRIVATE INTEREST: HaS THE LURE OF PROFITS CORRUPTED BIOMEDICAL RESEARCH? 27-55 (2003) (describing the development of university-industry collaboration); CORYNNE MCSHERRY, WHO OWNS ACADEMIC WORK?: BATTLING FOR CONTROL OF INTELlectuAl PROPERTY 154-62 (2001) (describing patents and academic incentives). 
law protects against various forms of the commons problem, ${ }^{78}$ which can be described by the prisoners' dilemma, a more apt description states that patent law resolves the problem of what game theorists call the "assurance game." 79 The assurance game better captures the economics, politics, and practices to which patent law responds. The assurance game provides an alternative to the social contract theory of patent law and provides a basis for understanding patents as market regulation and science policy. I make my argument in three stages. In subsection 1, I examine the economics of patent law using the tools of game theory. In subsection 2, I relate the economic understanding of patent law to the politics of patent lawmaking. In subsection 3, I demonstrate how the economic and political understanding of patents relates to the practice of inventorship.

\section{Economics of Patent Law: The Prisoners' Dilemma Versus the Assurance Game}

Economic justifications of patent law focus on the exclusivity created by the patent grant. At the macro level, such exclusivity allows the patent owner to generate extra-normal profits that can either be reinvested into research and development or used to recoup fixed research and development expenditures. ${ }^{80}$ Explanations for why competitive markets do not efficiently generate research and development and innovation rest on the economics of information-specifically, on Arrow's information para-

78. See, e.g., Michael A. Heller \& Rebecca S. Eisenberg, Can Patents Deter Innovation? The Anticommons in Biomedical Research, 280 SCI. 698 (1998); A. Samuel Oddi, The Tragicomedy of the Public Domain in Intellectual Property Law, 25 HASTINGS COMM. \& ENT. L.J. 1, 10 (2002).

79. For the key works of scholarship on the assurance game, also called the stag hunt game, see BrIaN SKYRMS, Evolution of THE SOCIAL CONTRACT 63-79 (1996) [hereinafter SKYRMS, SOCIAL CONTRACT] (discussing evolution of correlated conventions such as legal institutions); BRIAN SKYRMS, THE STAG HUNT AND THE EvOluTION OF SOCIAL STRUCTURE 4-13 (2004) [hereinafter SKYRMS, STAG HUNT] (discussing implications of stag hunt game for social contract theory); Theodore C. Bergstrom, Evolution of Social Behavior: Individual and Group Selection, 16 J. ECON. PERSP. 67 (2002) (exploring different implications for individual and group behavior of prisoners' dilemma and assurance game); Amartya K. Sen, Isolation, Assurance, and the Social Rate of Discount, 81 Q.J. ECON. 112 (1967) (presenting the assurance game as an alternative to the prisoners' dilemma). John Rawls acknowledged the assurance problem, although he does not analyze the problem as a formal game, and used the problem to explain why individuals in society would agree to accept fairness as a decision-making criterion. See RAWLS, supra note 54 , at $346-50$.

80. See Erich Kaufer, The Economics of the Patent System 24-41 (1989) (presenting a pure economic theory of patent law). 
dox. ${ }^{81}$ According to this paradox, once information is produced and disclosed to a second party, individuals are free, absent exclusivity, to disseminate and share the information. ${ }^{82}$ Because the marginal distribution costs of information are zero, a competitive market leads to information being distributed at a price of zero. A competitive price of zero, however, initially undermines the incentive to produce and distribute the information. The exclusivity of patent law resolves this paradox by limiting distribution of information to those individuals holding a license. This economic explanation supports a Lockean justification for patent law: society gives the creator the right to keep others from appropriating the invention. $^{83}$

The Lockean theory of patent law translates into a familiar game theory model of the state of nature and formulation of the social contract. Without intellectual property law, individuals either innovate or imitate. If everyone innovates, each individual benefits by an amount that we will designate as five. If one individual innovates and another imitates, then the imitator gains more than the innovator because he does not incur fixed costs of innovation. The innovator benefits less than he would if the other innovated because the innovator does not benefit from the other individual's innovation. To capture these facts, I will designate the benefit to the imitator as 6 and the innovator as 2. Finally, if both imitate, then they each benefit by an amount I will designate as 3 . These outcomes can be captured in Table 1 as follows:

TABLE 1: The Prisoners' Dilemma as a Problem of Imitation

\begin{tabular}{|l|l|l|}
\hline & Innovate & Imitate \\
\hline Innovate & 5,5 & 2,6 \\
\hline Imitate & 6,2 & 3,3 \\
\hline
\end{tabular}

Table 1 depicts a game that individuals play in a state of nature. The outcome of the game, or equilibrium, can be predicted as follows. If I expect the other individual to innovate, then I am better off imitating than innovating. Therefore, following my self-interest, I will imitate. If I expect the other individual to imitate, then once again my self-interest is to imitate. Because the situation is symmetric, the other individual will act simi-

81. See Kenneth J. Arrow, Economic Welfare and the Allocation of Resources for Invention, in THE RATE AND DIRECTION OF INVENTIVE ACTIVITY: ECONOMIC AND SOCIAL FACTORS 609 (R.R. Nelson ed., 1962).

82. Id. at 615 .

83. For a discussion of the Lockean view of intellectual property developed in a game theoretic context, see Wendy J. Gordon, Intellectual Property, in THE OXFORD HANDBOOK OF LeGAL STUdies 617, 624-25 (Peter Cane \& Mark Tushnet eds., 2003). 
larly in his interest. Consequently, everyone imitates, although all would be better off if everyone innovated. In a state of nature, pursuing individual interest leads to an outcome that is not socially optimal. If individuals could agree not to imitate through a social contract implemented through law, individuals would be better off. Patent law provides one form of social contract by granting an individual a property right in his innovation that allows punishment of impermissive imitation. ${ }^{84}$

This argument is familiar and takes many forms. One form of this game is the public goods justification for intellectual property law, which articulates the choice as contributing to the public good versus free riding. ${ }^{85}$ Under the public goods explanation, imitation is a type of free riding, while innovation contributes to the public good. Innovation is therefore encouraged by allowing the innovator to treat the innovation as private property and by enjoining the free-riding imitators. The defenses of intellectual property framed in terms of the commons make the same point. ${ }^{86}$ The intellectual commons is a public good to which innovators contribute and off which imitators free ride. Once again, the structure of the commons can be represented by the prisoners' dilemma game with the corresponding justification for intellectual property law. The resulting social contract consists of the following quid pro quo: the innovator obtains a right to exclude, and in exchange, society avoids the inferior outcome in which everyone imitates. This view of the social contract, implying a robust form of intellectual property protection, is consistent with the Lockean justification for intellectual property. Under the Lockean social contract, society grants an individual a right in the fruits of his labor against misappropriation to solve the prisoners' dilemma.

Criticisms of intellectual property, such as the anticommons theory, also employ a prisoners' dilemma game, ${ }^{87}$ although it is framed in terms of slightly different strategies. The creation of too many property rights in a given resource results in an anticommons. Under the terms of the anticommons, the state of nature entails a choice between sharing and privat-

84. Cf. id. at $640-41$ (applying the prisoners' dilemma to copyright).

85. See id. at $622-23$ (describing free riding and externality problems in intellectual property).

86. See, e.g., William M. Landes \& Richard A. Posner, The EConomic StruCTURE OF INTELlECTUAL PROPERTY LAW 14-15 (2003) (analyzing the economics of the commons).

87. See Ben Depoorter \& Francesco Parisi, Fair Use and Copyright Protection: $A$ Price Theory Explanation, 21 INT'L REV. L. \& ECON. 453, 459-61 (2002) (presenting formal model of anticommons problem as type of prisoners' dilemma); Lee Anne Fennell, Common Interest Tragedies, 98 Nw. U. L. REV. 907, 942-46 (2004) (describing anticommons problem as prisoners' dilemma). 
izing. Following the logic discussed previously, if both individuals share, each of them benefit by an amount of 5 . However, if one individual shares and the other appropriates, then the appropriator gains at the expense of the sharer. Once again, the appropriator benefits by 6 and the sharer by 2 . Finally, if both individuals appropriate, each gains 3 , which is less benefit than if the two shared. Therefore, theorists of the anticommons also represent the state of nature as a prisoners' dilemma. Society grants the right to exclude in exchange for the inventor's obligation to share.

Thus, the prisoners' dilemma provides an intuitive understanding for intellectual property. Proponents of strong rights can appeal to the innovate/imitate structure of the state of nature, while those who support weaker rights can appeal to the share/appropriate structure. The different structures represent different normative baselines for intellectual property with corresponding arguments for the structure of patent law, such as the range of patentable subject matter, the nonobviousness requirement, and the scope of infringement.

However, the prisoners' dilemma fails to adequately describe patent law in two ways. First, the prisoners' dilemma proves too much. In the prisoners' dilemma, imitating or free riding represents a dominant strategy. ${ }^{88}$ Consequently, it never pays to innovate or contribute unilaterally. This representation certainly overstates the case. In actual practice, individuals do share, particularly in research and scientific settings. ${ }^{89}$ Some academics criticize intellectual property because it undermines an academic culture of sharing that has existed as a norm for some time.$^{90}$ Under this view, the state of nature is one of communalism rather than selfinterest.

Second, the prisoners' dilemma does not aid in gauging the scale of intellectual property. ${ }^{91}$ For example, the prisoners' dilemma can be resolved

88. See SKYRMS, STAG HUNT, supra note 79 , at 2-3 (discussing dominant strategy in prisoners' dilemma).

89. See supra notes 75-76 and accompanying text. For a general criticism of prisoners' dilemma and other representations of collective action problems as ignoring the importance and reality of reciprocity, see Dan M. Kahan, The Logic of Reciprocity: Trust, Collective Action, and Law, $102 \mathrm{MICH}$. L. REV. 71, 76-77 (2003) (criticizing free riding and other similar arguments for ignoring reciprocity).

90. See KRIMSKY, supra note 77, at 107-09 (commenting on the commercialization of academia); MCSHERRY, supra note 77, at 191-93 (discussing the propertization of data); Kahan, supra note 89 , at $90-98$ (discussing importance of reciprocity for technological development).

91. See Michael Heller, The Boundaries of Private Property, 108 YALE L.J. 1163, $1188-91$ (1999) (discussing problems of boundaries, scale, and scope in the metaphors of property). 
if the game is repeated an infinite number of times. ${ }^{92}$ Under an infinitely repeated version of the game, individuals can support cooperation by punishing defectors. ${ }^{93}$ The key to this solution rests in the infinite duration of the game. If the game is of finite duration, then threats of punishment and actual punishment are ineffective because the best choice in the last period of the game is to defect. ${ }^{94}$ However, if defection dominates in the last period, it also dominates in the penultimate period. Therefore, in a finitely repeated version of the game, cooperation may not be supported. ${ }^{95}$ Under such a view, patents should be of infinite duration to prevent imitation of innovation. Yet infinite duration would contradict the requirement of rights of limited duration. ${ }^{96}$ Therefore, the prisoners' dilemma predicts both too much free riding and correspondingly overly strong intellectual property rights.

Those familiar with game theory will remember that the prisoners' dilemma can be resolved when repeated if the players do not know when the game will end. ${ }^{97}$ With some limitations, if the prisoners' dilemma is played with some probability that the game will end each period, then the result is the same as an infinitely repeated play of the game. ${ }^{98}$ This alternative solution provides some support for a probabilistic approach to patent rights under which the right can be terminated at any time because of a cancellation proceeding or invalidation. ${ }^{99}$ Such an approach results in a weaker version of intellectual property rights that is more protective of the public domain. ${ }^{100}$ However, as a conceptual basis for the patent bargain, such an approach fails because the terms are malleable subject to the normative position of the interpreter. As discussed above, the Supreme Court has interpreted the patent bargain in many ways, finding sometimes that exclusivity is granted in exchange for novelty and other times in exchange

92. See Robert AXELROD, THE EVOlution OF COOPERATION 53 (1984); SKYRMS, STAG HUNT, supra note 79, at 5; Bergstrom, supra note 79, at 69.

93. See Bergstrom, supra note 79 , at 70 .

94. See id. at 71.

95. See id.

96. See Eldred v. Ashcroft, 537 U.S. 186, 192-93 (2003) (stating that perpetual copyright term, and by inference patent term, would violate the limited times provision of U.S. CONST. art. I, § 8, cl. 8).

97. See SKYRMS, STAG HUNT, supra note 79 , at 8.

98. See id.

99. See Ian Ayres \& Peter Klemperer, Limiting Patentees' Market Power Without Reducing Innovation Incentives: The Perverse Benefits of Uncertainty and NonInjunctive Remedies, $97 \mathrm{MICH}$. L. REV. 985, 1007-12 (1999) (arguing that uncertainty in patent enforcement has important implications for duration and the limitation of the patentee's power).

100. See id. at $989-93$. 
for disclosure. ${ }^{101}$ Such flexibility allows patent rights and patent law interpretation to be tailored to differing factual and technological circumstances. ${ }^{102}$ But the open-endedness of the patent bargain as rooted in the prisoners' dilemma ultimately makes the social contract incoherent and unworkable.

The patent bargain as a quid pro quo of exclusivity for progress rests on the assumption that imitation is a dominant strategy in the state of nature. Because individuals will find it in their self-interest to copy absent laws prohibiting such activity, the social contract limits copying as much as possible. But this assumption is far from robust, as a slight modification demonstrates. Suppose that, in the state of nature, individuals will play the innovate/imitate game repeatedly along the terms described in Table 1. Assume that there is a fifty percent probability that, at the end of each play of the game, the game will end. Further assume that, if one person imitates, then the other player will also imitate for the rest of the game, and similarly for innovate. Mathematically, the new characterization of the state of nature can be represented as follows: ${ }^{103}$

TABLE 2: The Assurance Game and the Problem of Imitation

\begin{tabular}{|l|l|l|}
\hline & Innovate & Imitate \\
\hline Innovate & 10,10 & 5,9 \\
\hline Imitate & 9,5 & 6,6 \\
\hline
\end{tabular}

Note this repeated version of the game reaches two equilibria. Either both parties agree to innovate or both parties agree to imitate. Thus, unilateral imitation no longer dominates. This game is referred to as the "assurance game" because, if each player independently can be assured that

101. See supra text accompanying notes 17-29.

102. See Ayers \& Klemperer, supra note 99 , at 1027-28; Burk \& Lemley, supra note 45 , at $1670-87$.

103. The mathematical derivation works as follows. Under a probabilistic version of the game, there is a fifty percent chance that the game will be played again and fifty percent that it will not at each time period. This means that each payoff of the game has to be discounted by the probability that the game will actually be played during a particular time period. Suppose the two players start out reciprocating. Then there will be no need to retaliate and the players will reciprocate forever. The resulting payoff is 5 units discounted by the probability that the game will be played during a given period. The total payoff will be the sum of all of these discounted payoffs, an infinite series. The sum turns out to be 10, as presented in Table 2. Now suppose that one (or both) of the players fail to reciprocate. Then there will be retaliation forever under the terms of the game so that each play receives 3 discounted by the probability that the game will be played during a given period, another infinite series. The sums of those infinite series are presented in the Table 2 . 
the other will not imitate, then the innovation equilibria can prevail. ${ }^{104}$ In the prisoners' dilemma, no such assurance is possible, absent punishment of imitation, because imitation is the dominant choice.

I have two points about the assurance game. The first is that it is a better representation of the issues confronting patent law. The second is that the assurance game cannot readily be resolved by appeal to the quid pro quo of exclusivity for progress.

The assurance game serves as a better description of the underlying problem for patent law because individuals can assure each other not to imitate. Such assurance is the foundation of trade secret law. ${ }^{105}$ As a hybrid of tort, contract, and property law, trade secret law enables individuals to enter into private arrangements to limit imitation. ${ }^{106}$ The existence of such private arrangements questions the assumption that individuals dominantly choose to imitate. If imitation does not dominate, then the prisoners' dilemma is not an appropriate description of the world. Of course, the assurance game is not a perfect description, either. However, in being able to account for trade secret law, the assurance game acts as a better alternative to the prisoners' dilemma. ${ }^{107}$

In addition to providing an alternative to the prisoners' dilemma, the assurance game has other advantages. These can be seen if we reframe the problem, not as one of imitation or innovating, but one of disclosing and keeping secret. Both players would be better off if they disclosed because information can be shared and synergies can be realized. However, if one individual decides not to disclose, then the other individual would not disclose either. Such a structure can be represented as an assurance game, and we can refer to the game in Table 2, except with a change in the strategies.

104. See SKYRMS, SOCIAL CONTRACT, supra note 79, at 76-79 (discussing evolution of institution of property out of reciprocity described as correlated convention); SKYRMS, STAG HUNT supra note 79, at 10-13.

105. See LANDES \& POSNER, supra note 86, at 357-71; Richard A. Epstein, The Constitutional Protection of Trade Secrets under the Takings Clause, 71 U. CHI. L. REV. 57, 59 (2004).

106. See LANDES \& POSNER, supra note 86 , at $360-61$ (analyzing economics of trade secret law).

107. See Fennell, supra note 87 , at $945-47$ (comparing prisoner's dilemma with chicken game, a variation on the assurance game ); Kahan, supra note 89, 76-77, 90-91 (demonstrating the importance of reciprocity and trust in relationship with particular application to intellectual property). 
TABLE 3: The Assurance Game and the Problem of Disclosure

\begin{tabular}{|l|l|l|}
\hline & Disclose & Keep secret \\
\hline Disclose & 10,10 & 5,9 \\
\hline Keep secret & 9,5 & 6,6 \\
\hline
\end{tabular}

The structure of the game is exactly as described earlier. If both individuals disclosed their innovations, they are better off. However, if either individual opts out and decides to keep his innovation secret, the other's best alternative is to keep his own innovation secret in turn. Both the disclosure and the secret solutions are equilibria. This representation is closer to our understanding of the benefits of the patent system. The description echoes the Supreme Court's discussion of patents and trade secret in its Kewanee decision. ${ }^{108}$ According to the Court, the patent regime does not preempt the trade secret regime. ${ }^{109}$ Instead, the two complement each other. In terms of the assurance game, the patent regime and the trade secret regime are two equilibria outcome to an assurance game. Consistent with the Court's analysis, the patent system has advantages over the trade secret system, which is represented by the superiority of the disclosure equilibrium to the keep secret equilibrium. ${ }^{110}$

The parallel between the assurance game and the Court's discussion in Kewanee raises a compelling question. If the disclosure equilibrium is superior to the keep secret equilibrium, then why is the Kewanee dissent incorrect in arguing that trade secret law should be preempted by patent law? ${ }^{111}$ Preemption would eliminate the keep secret strategy, forcing people to disclose through patent. However, the answer rests in understanding what it means for an individual to keep an invention secret. Within the terms of the Kewanee case, inventions were kept secret through trade secret law. ${ }^{112}$ Within the terms of the assurance game, even if trade secret law were eliminated, individuals would still have the incentive to keep inventions secret through technological or social means if there was no assurance that others would disclose their secrets in turn. ${ }^{113}$ The more fundamental question is whether applying preemption to trade secret law would assure individuals that others would disclose their inventions. Since

108. See Kewanee Oil Co. v. Bicron Corp., 416 U.S. 470, 475-80 (1974).

109. Id. at 474 .

110. Id. at $480-84$.

111. Id. at 495 (Douglas, J., dissenting).

112. Id. at 474 .

113. See, e.g., Robert P. Merges, Rent Control in the Patent District: Observations on the Grady-Alexander Thesis, 78 VA. L. REV. 359, 376-77 (1992) (discussing various forms of secrecy). 
there are other ways to keep inventions secret besides trade secret law, the preemption of one regime does not assure that individuals will disclose through patents.

The assurance game, however, also fails to support the majority decision in Kewanee, which characterizes patent as a quid pro quo of exclusivity for disclosure. ${ }^{114}$ In the assurance game, if individuals believe that others will disclose, the disclosure equilibrium is sustainable. The quid pro quo proposed by the majority does not by itself provide this assurance. Instead, the patent bargain, as described by Kewanee, creates a bilateral relationship between the inventor and the state, under whose terms the inventor must disclose in exchange for protection of a property right in the invention. Disclosure is purely optional under these terms because the inventor can choose to protect his exclusivity through other means. Consequently, an inventor has no assurance that other inventors will disclose their inventions, and the assurance game may settle on the inferior equilibrium. Therefore, although the quid pro quo may resolve the prisoners' dilemma game, it does not resolve the assurance game that approximates the patent system more closely.

This argument calls into question the patent bargain metaphor. The assurance game, however, provides a basis for an alternative metaphor. At an abstract level, since the assurance game better describes the problem underlying patent law, then patent policy should be guided by the purpose of assuring inventors that other inventors will disclose their innovations. This purpose requires something more than the implementation of a quid pro quo in return for exclusivity. Patent law should create an environment within which assurance is guaranteed. Such a view of assurance is encompassed by the term "market integrity," $" 115$ as it is employed in securities regulation. ${ }^{116}$ Securities law, it is sometimes argued, creates market integrity, through the promotion of disclosure norms and the prosecution of fraud, and thus assures individuals that the marketplace is reliable. ${ }^{117}$ Similarly, patent law should be designed to create such assurance in the market for innovation and research and development. I provide examples

114. 416 U.S. at $480-81$.

115. See, e.g., Jonathan R. Macey, The Fraud on the Market Theory: Some Preliminary Issues, 74 CORNELL L. REV. 923, 926 (1989) (discussing market integrity); see also Francis Fukuyama, Trust: The Social Virtues and The CREation of Prosperity 23-32 (1995) (characterizing trust as a requirement for creating large business entities).

116. See, e.g., Macey, supra note 115. For a discussion of market integrity in the securities case law, see Basic v. Levinson, 485 U.S. 224, 246 (1988).

117. On disclosure norms, see Richard McAdams, Group Norms, Gossip, and Blackmail, 144 U. PA. L. REV. 2237, 2284 (1996); Eric L. Talley, Disclosure Norms, 149 U. PA. L. REV. 1955, 1961 (2001). 
of this in Part IV, but one application illustrates the parallel with securities law. Patent law regulates public disclosure of the invention through the enablement requirement and the public use bars. These doctrines serve to assure inventors about disclosure norms in the marketplace. The limited duration of patent exclusivity is a striking example of such assurance; inventors are guaranteed that, under the Constitution, exclusivity will expire, making the invention available for anyone to use. Moreover, patent law consists of more than a bargain between the inventor and the state; it includes other parties, such as consumers of the invention, follow-on inventors, students of the knowledge created by the innovation, and disseminators of the invention through market and non-market processes.

Scholars have appealed to the assurance game as a tool for analyzing the evolution of social institutions. ${ }^{118}$ The two equilibria of the game represent two separate possible evolutionary strategies that can be played against each other to analyze the conditions under which social organizations evolve towards cooperation. ${ }^{119}$ For example, these two equilibria of the assurance game may represent two different industries, one reliant upon secrecy and the other reliant upon disclosure. The evolutionary approach lends itself to analysis over which of these two industries would be more likely to survive. ${ }^{120}$ Similarly, the two different equilibria could represent two different intellectual property regimes. Here, the evolutionary approach permits consideration of which regime would tend to dominate over time. ${ }^{121}$ Patent law does not simply protect an inventor's right to exclude-it regulates primary behavior and seeds norms of disclosure and innovation in affected industries.

\section{The Administration of Patent Law and Policy}

The discussion of the strategic and economic issues raised by patent law aids in understanding the relationship between the administration of patent law and the regulations of patent law and policy. Within the United

118. See SKYRMS, SOCIAL CONTRACT, supra note 79 , at 76-79 (discussing evolution of property); SKYRMS, STAG HUNT, supra note 79, at 87-104.

119. See SKYRMS, STAG HUNT, supra note 79, at 105-09; Bergstrom, supra note 79, at 83-84.

120. See, e.g., Robert P. Merges, Institutions for Intellectual Property Transactions: The Case of Patent Pools, in EXPANDING THE BOUNDARIES, supra note 74, at 123, 133 35.

121. See Jerome H. Reichman, Of Green Tulips and Legal Kudzu: Repackaging Rights in Subpatentable Innovation, in EXPANDING THE BOUNDARIES, supra note 74, at 23, 25-29; PETRA MOSER, How Do PATENT LAWS INFLUENCE INNOVATION?: EVIDENCE FROM NINETEENTH-CENTURY WORLD FAIRS (Nat'l Bureau of Econ. Research, Working Paper 9909, Aug. 2003). 
States, recent scholarly and popular criticism of intellectual property legislation has concentrated on copyright law, especially the impulse for digital rights management. ${ }^{122}$ However, on the international stage and throughout the history of intellectual property, patent law has been of equal, if not greater, importance. ${ }^{123}$ In 2003, the FTC's white paper on patent reform brought the issue of patent law and competition policy into prominence from an administrative viewpoint. ${ }^{124}$ Currently, the control of pharmaceutical pricing continues to be of concern across many demographic groups and political constituencies globally. ${ }^{125}$ The pharmaceutical pricing issue is a particularly striking example of the intersection of patent law and regulation. ${ }^{126}$ However, the social contract view of patents fails to address these and other salient issues.

Social contract's failure rests on its inability to address patent administration. ${ }^{127}$ If the patent bargain results from a discrete transaction between the inventor and the state, then the patentee seemingly is free to act within the terms of the grant. The terms cannot be renegotiated absent consent of the parties or changed circumstances allowing the grant to be rescinded or reinterpreted. Under such a strict view, the original agreement, entered at some historical moment, limits any attempts to redress the inequitable exercise of the patent right. This moment is not necessarily the patent issue date; under social contract theory, that the moment could be the date the Patent Act was passed by Congress or, perhaps, the authorization of Congress to pass the Patent Act under Article I, Section 8, Clause 8. This originalist view reduces the concept of patent administration to the mechanical application of a previously agreed to bargain rather than a pragmatic, contextual, day-to-day application of the law to particular facts. ${ }^{128}$

122. See Shubha Ghosh, Deprivatizing Copyright, 54 CASE W. RES. L. REV. 387, 394-400 (2003).

123. See KAUfER, supra note 80 at 1-10; James Boyle, The Second Enclosure Movement and the Construction of the Public Domain, 66 LAW \& CONTEMP. Probs. 33, 56-57 (2003).

124. FTC REPORT, supra note 16; see discussion infra Part IV.C.

125. See, e.g., James Thuo Gathii, The Legal Status of the Doha Declaration on TRIPS and Public Health Under the Vienna Convention on the Law of Treaties, 15 HARV. J.L. \& TECH. 291, 293-96 (2002).

126. See, e.g., James Thuo Gathii, Construing Intellectual Property Rights and Competition Policy Consistently with Facilitating Access to Affordable Aids Drugs to Lowend Consumers, 53 FLA. L. REV. 727, 770-74 (2001) (discussing the relationship between patent law and FDA regulatory review).

127. See Rubin, supra note 4, at 14-15 (criticizing social contract theory as unhelpful in understanding the modern administrative state).

128. See Lawrence Lessig, Free Culture: How Big Media Uses Technology AND THE LAW TO LoCK DOWn Culture AND CONTROL CREATIVITY 213-48 (2004). 
Although there is nothing wrong per se with mechanical administration, it remains to be seen whether such a mechanical approach addresses the pressing issues raised by patent law, such as the pharmaceutical pricing and unfair competition questions mentioned above.

The relational theory of contracts offers a possible, but ultimately unsatisfactory, cure of the mechanical application of patent law. Legal theorist Ian McNeil's case for relational contracts describes non-discrete relationships, such as that between an employer and an employee. ${ }^{129}$ The patent bargain may also fit the model of the relational contract, particularly if we view the patent owner and the state as engaging in a long-term, openended contract. A relational contract view of the patent bargain may confirm a regulatory perspective on patent law, but the approach is an unsatisfying compromise. The patent bargain between the inventor and the state evolves partly because other interests might develop over time. ${ }^{130}$ For example, drug prices may escalate, depriving the innovation to those who most need it. Alternatively, patents may create research bottlenecks in certain areas that are only resolved through judicious application of patent misuse doctrine or antitrust law. Characterizing these issues as new dimensions that demand that the patent bargain evolves ignores that the two examples implicate interests that need to be incorporated into the patent bargain. A relational view of the bargain might suggest that either the contract negotiation expands over time or that the contract implicates third party interests, but these complications are spandrels added onto a misguided metaphor. The social contract view of patent law, even in a relational form, ignores the political realities of how patent administration implicates a host of interests that cannot be effectively addressed through a bargain model. ${ }^{131}$

129. See IAN R. MACNEIL, The New Social ConTRACt: AN INQUIRY INTO MODERN CONTRACTUAL RELATIONS 47-48 (1980). For a thorough criticism of the relational contracting perspective, see Randy E. Barnett, Conflicting Visions: A Critique of Ian Macnei's Relational Theory of Contract, 78 VA. L. REV. 1175, 1178-82 (1992).

130. See, e.g., Robert P. Merges, Intellectual Property Rights and the New Institutional Economics, 53 VAND. L. REV. 1857, 1868-70 (2000) (analyzing the political economy of intellectual property rights in historical and evolutionary terms).

131. For a discussion of the administrative complexities of patent law, particularly with respect to the applicability of the Administrative Procedure Act to the United States Patent and Trademark Office, see Craig Allen Nard, Deference, Defiance, and the Useful Arts, 56 OHro ST. L.J. 1415, 1419-25 (1995). Professor Orin Kerr is critical of Professor Nard's administrative view of patent law. See Orin Kerr, Rethinking Patent Law in the Administrative State, 42 WM. \& MARY L. REV. 127 (2000) (presenting a purely private law model of patent law that expressly describes patents as a contract). 
Professor Ed Rubin describes the problem with social contract as grounding statecraft on an idealized notion of promisekeeping. ${ }^{132}$ As applied to patent law, the social contract view posits the patent grant as a promise by the state in exchange for a return promise by the inventor. According to Rubin, government, whether in the case of patent law or in other instances where social contract theory is applied, is not that simple. ${ }^{133}$ While bargaining is undoubtedly a key part of the legislative process, bargains are sustained through the play of interests, not through a gentlemanly notion of honor in an individual's word. Furthermore, legislative bargaining differs from contract negotiation because the former involves multiple interests while the latter is essentially a bilateral relationship.

Similarly, patent rights do not rest on a foundation of promisekeeping. To reduce the patent grant to property requires accepting uncritically the status of patent as property. The quid pro quo of patent exchange is a promise from the state to protect property in return for the inventor's promise to innovate. Yet there is certainly more to patent law than that. As the substantial literature and case law on the relationship between patent law and antitrust indicates, the patent grant implicates competition policy. ${ }^{134}$ The exclusion of patents from the Statute of Monopolies is not to the contrary. The exclusion of patents from U.S. antitrust law and the debate over their treatment indicate the jurisdictional concerns of how to balance exclusivity in the marketplace while maintaining a commitment to competition. ${ }^{135}$ For pharmaceutical patents, the grant of a patent entails more than an exchange of promises. ${ }^{136}$ Patents structure the market for pharmaceuticals as much as the Food and Drug Act (FDA), albeit through different means. ${ }^{137}$ Reducing the FDA to a contract, a grant of government approval in exchange for the provision of safe drugs, ignores the subtleties of drug regulation. Similarly, reducing patent law to a contract ignores the

132. See Rubin, supra note 4; see also discussion supra Part II.A.

133. See Rubin, supra note 4.

134. For a survey of the literature and case law, see Michael A. Carrier, Unraveling the Patent-Antitrust Paradox, 150 U. PA. L. REV. 761, 807-15 (2002); Willard K. Tom \& Joshua A. Newberg, U.S. Enforcement Approaches to the Antitrust-Intellectual Property Interface, in COMPeTITION POLICy AND InTELlectual Property Rights IN THE KNOWLEDGE-BASED ECONOMY 343-75 (Robert D. Anderson \& Nancy T. Gallini eds., 1998).

135. See FTC REPORT, supra note 16, Executive Summary, at 3-10; Carrier, supra note 134 , at 848-52.

136. See Gathii, supra note 126; Shubha Ghosh, Pills, Patents, and Power: State Creation of Gray Markets as a Limit on Patent Rights, 53 FLA. L. REV. 789, 799-802 (2001).

137. See Gathii, supra note 126. 
subtleties of patent regulation, thereby reducing the law to a property protection tool.

The prisoners' dilemma reflects the implicit reliance on exclusivity. With its prediction that imitation will be a dominant strategy in the state of nature, the prisoners' dilemma supports a legal regime that protects exclusivity and detracts from other models of law. In contrast, the assurance game supports patent administration as a means to ensure "market integrity," akin to securities regulation, as described in Part II.B.1. Although patent economics exclusively focuses on the market, I argue that effective patent administration must consider other institutions to create effective patent policy to solving the assurance game. ${ }^{138}$ This conclusion contrasts sharply with an approach grounded in the prisoners' dilemma that tends to reduce patent law to a means of protecting property. Two examples illustrate the difference.

First, consider the relationship between patent prosecution and patent litigation, an issue that poses the familiar problem of the relationship between agencies and courts. ${ }^{139}$ The prisoners' dilemma does not provide guidance for resolving this problem. If the state's goal is to protect property, then patent prosecution serves largely to define the metes and bounds of one's property interest, much like a deed of title. Such a legal description facilitates the protection of property in subsequent litigation. However, the assurance game suggests a deeper relationship between prosecution and litigation. If the purpose of patent law is to create assurance, to permit parties to reconcile conflicting beliefs over how other actors will act, then the agencies and courts should be designed to work together to ensure trust in patent administration and market integrity. ${ }^{140}$ For example, as discussed below, preliminary injunction analysis in patent law often reinforces the conception of the patent grant as a protected property right and ignores the effects on the public interest, particularly on competition. The regulatory approach I advocate would focus attention on these concerns.

138. See Merges, supra note 130.

139. See Mark A. Lemley, Rational Ignorance in the Patent Office, 95 Nw. U. L. REV. 1495 (2001); Arti Rai, Engaging Facts and Policy: A Multi-Institutional Approach to Patent System Reform, 103 CoLUM. L. REV. 1035, 1122-27 (2003).

140. See Shubha Ghosh \& Jay Kesan, What Do Patents Purchase? In Search of Optimal Ignorance in the Patent Office, 40 Hous. L. REV. 1219, 1250-51 (2004); Rai, supra note 139 , at $1040-41$. 
To illustrate, consider replacing prosecution and litigation with registration and litigation similar to copyright. ${ }^{141}$ Litigation both defines the scope of one's property right and determines whether that right has been infringed. Under a registration and litigation system, an inventor has no reason to believe that others will invent rather than imitate, and inventors therefore will tend to settle on the imitation equilibrium rather than the innovation equilibrium in Table 2 . In particular, consider the disclose/keep secret depiction of the assurance game in Table 3. A registration system lacks assurance that others will disclose. Therefore, a patent system designed along the lines of the current U.S. copyright system will result in a trade secret-like regime with inventors settling on the inferior keep secret equilibrium rather than the disclosure equilibrium. If properly designed, a prosecution system resolves this problem by requiring review of an invention for innovation, tantamount to state certification, that the invention meets certain criteria of innovation. Thus, a prosecution system can resolve the assurance game while a registration system cannot. ${ }^{142}$

Second, patentable subject matter provides a second example of how social contract theory fails to adequately describe patent law. European patent law, as well as the law of several Asian countries, permits excluding patentability on the grounds of morality or public order. ${ }^{143}$ The United States lacks such patent restrictions in favor of state and federal regulation of specific fields. ${ }^{144}$ For example, a genetically modified vegetable may be denied a patent in Europe; while in the United States, a patent most likely will issue, but the vegetable would be subject to state and federal agricultural regulation. ${ }^{145}$ United States patent law decouples patent law's focus on innovation from the state's power in managing health and safety. ${ }^{146}$ Other regimes, by contrast, fold in the state's police power into the administration of patents. ${ }^{147}$

141. See F. Scott Kieff, The Case for Registering Patents and the Law and Economics of Present-Obtaining Rules, 45 B.C. L. REV. 55 (2003), for an analogous discussion.

142. See Ghosh \& Kesan, supra note 140, at 1248, for further discussion.

143. For an overview, see Margo Bagley, Patent First, Ask Questions Later: Morality and Biotechnology in Patent Law, 45 WM. \& MARY L. REV. 469, 473-77 (2003). See also discussion infra Part IV.A.

144. See Juicy Whip, Inc. v. Orange Bang, Inc., 185 F.3d 1364 (Fed. Cir. 1999).

145. See, e.g., Greenpeace, Ltd. v. Plant Genetic Sys. N.V., 28 IIC 75 (1997).

146. Professor Bagley argues against such decoupling. See Bagley, supra note 143, at 516. For a response, see discussion infra, Part IV.A.

147. See Webber v. Virginia, 103 U.S. 344, 347-48 (1880) (stating that patent law did not displace police power). For a discussion of the relationship between intellectual property and the police power, see Ghosh, supra note 122, at 402-03. 
These difficult questions of patent administration are not within the purview of social contract theory. Reducing patents to a bilateral exchange, as social contract theory does, fails to incorporate issues like administration and morality into the contract. Perhaps the language of social contract can encompass these concerns as additional terms or conditions limiting the reach of the contracting powers. However, once these complications are introduced, the appeal of social contract theory gives way to more refined theories of the state and regulation - theories that go beyond the simple predictions of the prisoners' dilemma.

The assurance game considers some overlooked dimensions of the debate over the limitations of morality and the public order. Denying patentability forces inventors of immoral or unsafe inventions to resort to trade secret law or self-help for protection. As has been pointed out by other commentators, denial of patenting does not necessarily mean suppression of the invention. ${ }^{148}$ Thus, recourse to trade secret law permits the existence and dissemination of undesirable inventions. Furthermore, secrecy makes regulation of these inventions through general health and safety laws more difficult, because the inventions may escape the sunlight of disclosure. ${ }^{149}$ As a result, denial of patentability is undesirable under the terms of the assurance game not because of the stronger property protection, but rather because of the effects on the ability to regulate and promote market integrity. ${ }^{150}$ The assurance game redirects our attention from patent as property to patent as a regulatory tool designed to assure players that others can be trusted in the process of innovation. What this means in practice will be explained in Section C, after I address the third piece of the patent puzzle: the implications of the assurance game for the practice of inventors in the various fields to which patent law applies.

\section{Patent Law and Inventorship}

As a representation of inventors' behavior, the prisoners' dilemma suffers from a basic flaw: it limits the invention process to a simplistic choice between innovation and imitation. Misleadingly, the game predicts that imitation will be a dominant strategy and that individuals will choose to imitate, absent legal or other sanctions, in all circumstances. The actual

148. See, e.g., Cynthia Ho, Splicing Morality and Patent Law: Issues Arising from Mixing Mice and Men, 2 WASH. U. J.L. \& POL'Y, 247, 247-48 (2000) (stating that seekers of patent were planning to repress the invention).

149. See Ruckelshaus v. Monsanto Co., 467 U.S. 986 (1984).

150. To put this another way, the grant of a patent creates a legal interest that can be regulated just like property can be regulated. For a discussion of how law creates regulable interests, see JAMES C. SCOTT, SEEING LiKE A STATE 53-84 (1998). 
practice of invention suggests otherwise. Academic culture, to a certain extent, has existed in many settings based on the ethic of sharing, meaning not that academics are never mean to each other, but that scientific and scholarly insights are often freely and openly distributed and discussed outside the realm of private property and the marketplace. ${ }^{151}$

Robert Merton, a noted sociologist of science, has documented "the commons of science" where "the give and the take both work to enlarge the common resource of accessible knowledge."152 Although Merton refers to the scientific culture as "communism," self-interest has not given way to altruism. ${ }^{153}$ Competition in the science commons rests on "recognition and esteem as the sole property right of the scientists in their discoveries." ${ }^{154}$ The motivating force is being the first to discover, not the first to appropriate. In terms of the assurance game, Merton's description suggests that scientists manage to reach the superior equilibrium by creating an environment of trust and assurance that each will work towards the same goal. Thus, Merton describes the repeated version of the prisoners' dilemma, which as described above, leads to the assurance game.

Even purely commercial settings illustrate features of Merton's commons of science. In response to the controversy over business method patents, Robert Crandell stated that neither he nor other entrepreneurs ever thought of seeking patent protection for business innovations, such as the frequent flyer program or a credit card. ${ }^{155}$ The imitation of profitable ideas stokes competition, and entrepreneurs flourish by deriving the next big idea and implementing it, rather than seeking to protect innovations as property. Describing U.S. industrial development in the late nineteenth century, Alfred Chandler notes: "Unpatented proprietary knowledge, 'trade secrets', and broad, product-specific knowledge and experience created far more powerful barriers to entry than did patents." tion matches the commons of science in one important way: innovation

151. See Arthur Kornberg, The Golden Helix: Inside Biotech Ventures 13-17 (1995) (describing the conflict between academic and industry research norms); MCSHERRY, supra note 77; Lynne G. Zucker et. al., Collaboration Structure and Information Dilemmas in Biotechnology: Organizational Boundaries as Trust Production, in TRUST IN ORGANIZATIONS: FRONTIERS OF THEORY AND RESEARCH 90, $96-99$ (Roderick M. Kramer \& Tom R. Tyler eds., 1996).

152. MERTON, supra note 75 , at 332 .

153. Id. at 271-74.

154. Id. at 272 .

155. See Julia Ungwin, 'Business Method' Patents, Key to Priceline, Draw Growing Protest, WALL ST. J., Oct. 3, 2000, at B1.

156. Alfred D. Chandler, JR., SCAle and Scope: The Dynamics of Industrial CAPITALISM 228 (1990). 
and development occurs not through the acquisition of property rights, but through achieving first place. The internalized norm is one of innovation rather than imitation, contradicting the prediction of the prisoners' dilemma and the Lockean social contract.

Of course, the notion of competition and the prisoners' dilemma are not incompatible. As I discussed in Part II.A, the prisoners' dilemma, played over time with players threatening each other with sanction if they cheat, is identical in structure to the assurance game. The question is whether social behavior implemented by norms resolves the problem of the assurance game without the intervention of law. Merton's description of the commons of science suggests that such success without law might be possible. Crandall's assessment of business methods and Chandler's emphasis on "knowledge and experience" as being key predictors of industrial success suggest that market competition might by itself spur innovation. If these two examples are erroneous and not indicative of all areas of innovation, then patent law can possibly correct the failure and aid in resolving the assurance game. Even if they are true, patent law still can serve an important function in resolving the assurance game. By setting general rules that apply across different markets and industries, patent law can seed norms that become incorporated into social behavior. ${ }^{157}$ Two examples illustrate this point: the lack of an independent invention defense and the existence of the public use bars.

In contrast to patent law, copyright recognizes an independent inventor defense, because copyright law regulates foremost the act of imitating. ${ }^{158}$ In contrast, patent law regulates any unauthorized use of the patented invention. ${ }^{159}$ The assurance game offers a succinct explanation for this key difference. ${ }^{160}$ The lack of an independent inventor defense in patent law assures each inventor that other inventors are predisposed to engage in innovative activity rather than imitative activity. Furthermore, the lack of the

157. For a discussion of the role of legal institutions in seeding norms for science, see PHILIP KITCHER, SCIENCE, TRUTH, AND DEMOCRACY 117-30 (2001) (discussing the norm of "well-ordered science"). A similar norm-seeding function for trademark is proposed by Graeme Dinwoodie. See Graeme B. Dinwoodie, The Death of Ontology: A Teleological Approach to Trademark Law, 84 IowA L. REV. 611, 680-84 (1999).

158. See Clarissa Long, Information Costs in Patent and Copyright, 90 VA. L. REV. 465, 525-33 (2004).

159. See Sheldon v. Metro-Goldwyn Pictures Corp., 81 F.2d 49, 54 (1936) (Judge Hand presenting famous example of Ode on a Grecian Urn, explaining that copyright prevents imitation and protects original, even if duplicative, creations).

160. See Long, supra note 158 , at 530 (presenting an explanation based on patent law's concern with constructive notice); Roger D. Blair \& Thomas F. Cotter, Strict Liability and Its Alternatives in Patent Law, 17 BERKELEY TECH. L.J. 799, 810 (2002). 
defense supports a disclosure equilibrium in the second version of the assurance game described in Table 3 . By protecting the party who invents first, patent law encourages early disclosure, thereby creating assurance that other inventors do not withhold innovations. Accordingly, the concerns of copyright lie elsewhere. Unlike patent law, copyright's domain is individual expression that is original to the creator. Patent's domain, by contrast, is the field of innovation, rather than the personal expression of the inventor. By denying an independent inventor defense, patent law seeds a norm of innovation and aids in instituting such social practices as searching a field before beginning one's research and development. Copyright promotes more spontaneous, self-expressive creativity. ${ }^{161}$

The public use bars provide another example of how patent law can seed norms that can aid in resolving the assurance game. In the United States, public use bars deny patent issuance if the invention has been used one year prior to the submission of the application. ${ }^{162}$ In Europe, within a six month grace period, any public use before the application filing date makes the invention unpatentable. ${ }^{163}$ The public use bars are inconsistent with the prisoners' dilemma but consistent with the assurance game. If, as the prisoners' dilemma implies, the purpose of patent law is the creation of property rights to prevent imitation, then why does the United States limit these rights based on uses prior to the submission of the application? The assurance game offers a more coherent explanation for the limitation. For example, the on-sale bar prevents the patent applicant from selling or offering to sell the invention before the filing date. While marketing certainly permits earlier dissemination of the invention, the bar is designed to assure that the invention is disseminated to the community broadly rather

161. For a discussion of copyright's role in protecting expressive activity and its potential conflict with functionality, see Lloyd Weinreb, Copyright for Functional Expression, 111 HARV. L. REV. 1149, 1163-71 (1998). The statement in the text seems to be contradicted by the extension of copyright to software which is arguably not the type of personal expression that I am arguing copyright favors. For a discussion of the expressive function of software, and the problems of treating it as speech for First Amendment purposes, see Dan L. Burk, Patenting Speech, 79 TEX. L. REV. 99, 105-09 (2000).

162. See 35 U.S.C. $\S 102$ (a)-(b) (2000). I am not suggesting that the current doctrinal interpretation on the public use bars is coherent and transparent. A reading of $P$ faff $v$. Wells Electronics, Inc., 525 U.S. 55 (1998), and subsequent commentary should cure any such perception. See Timothy R. Holbrook, The More Things Change, The More They Stay the Same: Implications of Pfaff $\mathrm{v}$. Wells Electronics, Inc. and the Quest for Predictability in the On-Sale Bar, 15 BERKELEY TECH. L.J. 933, 941-55 (2000).

163. See, e.g., A. Jose Cortina, When is Absolute Novelty Not Absolute Novelty?, 4 INTELL. PROP. TODAY 30-31 (1997). 
than to specific parties with whom the inventor contracts. ${ }^{164}$ In this way, each inventor is assured that other inventors are engaged in innovation and disclosure without creating localized markets for the invention. Of course, an inventor can always choose to disclose the invention broadly and not patent, but the public use bars put the inventor to precisely that choice. As a result, norms about selling and using an invention are seeded to modulate social behavior in the innovation process.

\section{Patent Law, Private Orderings, and the Well-Regulated Marketplace}

The metaphor of the patent bargain rests on a naive view of social contract theory, based on questionable assumptions about private orderings, that reduces patent law to a tool for protecting property rights. The questionable behavioral assumption is that individuals will always choose to imitate innovations and never choose to innovate unilaterally. This assumption, captured by the prisoners' dilemma, implies that patent law's primary goal is to prevent imitation by creating strong property rights in inventions. By considering the assurance game as an alternative description of behavior, I argue that private reciprocity is possible and that patent law's primary role is to create assurances to foster reciprocity. Patent law should not be understood against a background of laissez-faire and unfettered markets. Instead, patent law should be guided by the principle of creating a well-regulated marketplace that fosters reciprocal behavior in the choice of private orderings.

The term "well-regulated marketplace" may be dissatisfying to those who are concerned about the trend towards commodifying knowledge, as occurs when basic scientific ideas are allowed to be patented. ${ }^{165}$ However, the key to the argument is the emphasis on regulation rather than on the marketplace. I do not endorse laissez faire, I endorse regulation of the marketplace and recognition that the marketplace itself is a tool of administration. The question becomes how to appropriately structure and regulate the marketplace. For patent law, the difficult issue is reconciling the marketplace with other institutions, such as universities, not-for-profit research communities, and public interest organizations, that seek to tap in-

164. For an elaboration this point, see David W. Carstens \& Craig Allen Nard, Conception and the "On Sale" Bar, 34 WM. \& MARY L. REV. 393, 395 (1993) (describing the policy of prompt and widespread disclosures of invention to the public).

165. See, e.g., KRIMSKY, supra note 77, at 75-79; MCSHERRY, supra note 77 , at 49 50 (describing communal norms in science). 
vention to prevent harm. ${ }^{166}$ The social contract view of patent as a quid pro quo ignores these interests. The assurance game recognizes them and forces us to think how a well-regulated marketplace incorporates these noncommercial values.

Economist and political scientist Charles Lindblom captures my thoughts with his description of the market as a "state administrative instrument." "167 Under this description, the market is a means of statecraft, not an end in itself. Lindblom argues that the market provides a mechanism through which conduct can be regulated and certain problems of resource allocation solved. Like all policy instruments, the use of free markets should be contested and assessed, in the same way that democratic societies would assess tax policy, legislation, and economic subsidies. ${ }^{168}$

Patent law fits neatly into Professor Lindblom's view of markets as an instrument of administration. Historically, patents were a grant by the sovereign conveying exclusivity over certain activities, such as mining, and evolved into grants that conveyed exclusivity in the marketing of certain novel inventions. ${ }^{169}$ The Statute of Monopolies, which limited the sovereign's power to grant certain types of market exclusivity, exempted patents. ${ }^{170}$ As a grant, patents shaped the creation and development of markets. Under modern law, patents serve as a way to administer and organize markets. When scholars speak of patents as addressing market failures, patents are described as an administrative tool. ${ }^{171}$ Yet scholars have not fully explored and appreciated the scope of patents as administrative tools. Instead, the social contract view of patents has reduced the patent grant to a quid pro quo: the purchase of progress in exchange for exclusivity. The view of patent as reward emphasizes only one dimension of the patent in-

166. For a discussion of patent law's relationship to noncommercial activities, see Arti K. Rai, Regulating Scientific Research: Intellectual Property Rights and the Norms of Science, 94 Nw. U. L. REV. 77, $81-88$ (1999); Katherine J. Strandburg, What Does the Public Get? Experimental Use and the Patent Bargain, 2004 WIS. L. REV. 81, 135-38 (importance of experimental use limitation on patents for non-profit entities).

167. See Charles Lindblom, The Market System: What It Is, How It Works, AND WHAT TO MAKE OF IT 258 (2001).

168. See id. at 271.

169. See KAUFER, supra note 80 , at 2-3.

170. Statute of Monopolies, 21 Jam. I, 3 (1623) (Eng.).

171. See, e.g., LANDES \& POSNER, supra note 86, at 35-36 (pointing out the central role of the state in regulating the system of intellectual property in contrast with real property). 
strument - compensation for invention-and ignores the role of patents as means of regulating markets. ${ }^{172}$

Admittedly, viewing patents as a quid pro quo resolves the problem of patents as a form of patronage bestowed by the sovereign. ${ }^{173}$ If patents are a quid pro quo, the patentee must have done something to earn the privilege, but the justification for patents as quid pro quo is subject to the same criticism that is often aimed at quid pro quo as ethical justification for a free market. ${ }^{174}$ If it is true that a patentee gets only what he deserves, the problem arises as to who determines the meaning of desert. ${ }^{175}$ The patenting of seemingly trivial inventions suggests that the standard has declined. ${ }^{176}$ But if patents and the patent system are looked upon with skepticism by many, the failure results from the quid pro quo justification and the lack of any basis for measuring how much and what has to be given up by the inventor to warrant exclusivity. ${ }^{177}$ In contrast, recognizing patents' role in regulating markets creates a vital role for patents. The alternative I propose is not designed to justify the current patent regime or to explain why patents on cat hammocks or business method patents are desirable. In fact, these patents become more nonsensical once the market regulatory view of patents is accepted. Patents, in these cases, serve no market regulatory function. The quid pro quo view, however, may always leave one wondering in the case of trivial patents: perhaps the inventor deserved the grant, because who is to say what merit is?

The problem of merit illustrates a potential conflict between the patent bargain metaphor and democratic values. If a patent rewards invention, then a democratic society should be concerned with who determines the amount of the reward. ${ }^{178}$ Usually, democracies appeal to the market to determine the rate of the reward. ${ }^{179}$ Society regulates the market to assure a fair and equitable return. ${ }^{180}$ Patent law adopts this model by giving the in-

172. For a criticism of the reward theory of patent, see Michael Abramowicz, Perfecting Patent Prizes, 56 VAND. L. REV. 115, 127-58 (2003).

173. See Christine MacLeod, InVenting the Industrial Revolution: The EngLISH PATENT SYSTEM, 1660-1800, at 24-30 (1988).

174. See LINDBLOM, supra note 167 , at 117-19.

175. See id. at 118 .

176. See, e.g., John R. Allison \& Emerson H. Tiller, The Business Method Patent Myth, 18 BERKELEY TECH. L.J. 987, 1077 (2003) (describing how the nonobviousness requirement has become more slack).

177. See id. at 1077-78 (discussing subjectivity of patent granting process).

178. See LINDBLOM, supra note 167, at 207-08 (discussing how democratic systems are concerned with the distribution of rewards in a market society).

179. See id. at 226-27.

180. See id. at 102-06. 
ventor a property right in her invention with a resulting exclusivity that permits marketing the patent. The conflict with democracy arises in defining the breadth of the exclusivity and the selection of inventions deserving of such exclusivity. The recent trend towards laxity in patenting may suggest the democratization of patent law. ${ }^{181}$ However, this characterization contradicts the exclusivity which may in many instances result in competition dampening conduct. ${ }^{182}$

A regulatory view of patent resolves the tension between patent law and democracy. Once patent law is viewed as a means to regulate certain behavior and to establish market integrity, then patent law works like antitrust law, securities law, consumer protection law, and a host of other regulations that democratic countries enact to bring market values and democratic values in line. ${ }^{183}$

Although numerous scholars, including myself, have argued that copyright law should be understood as democracy enhancing, ${ }^{184}$ none have previously linked patent law and democracy. ${ }^{185}$ A regulatory approach turns attention to how patent law helps to establish well-regulated markets and reveals the link between patents and democracy. If, as the regulatory approach implies, patent law consists of market regulation, and if, as common perception suggests, patent law focuses on science, then patent law provides a connection between science and the well-regulated marketplace. To emphasize, I do not simply mean that patent law creates a property right in science that permits commercialization. Rather, I view patent law as both a form of science policy and a form of market regulation. The assurance game can explain how this is true in theory and also provide a way to reconcile this dual purpose of patent law in practice.

The assurance game captures the role of patents as a regulatory tool. While the prisoners' dilemma predicts that individuals will not cooperate, the assurance game suggests that cooperation is possible where individuals can be assured cooperation of others. Under the terms of the assurance

181. See Allison \& Tiller, supra note 176, at 1078 (describing lowering of standards for patentability).

182. See Bonito Boats, Inc. v. Thunder Craft Boats, Inc., 489 U.S. 141, 150 (1989) (explaining how novelty and nonobviousness criteria in tandem further values of competition and exploitation of public domain knowledge).

183. See LINDBLOM, supra note 167 , at $262-63$ (describing various forms of market control and their role in a democratic society).

184. See, e.g., Ghosh, supra note 122.

185. A search of the law review databases did not find any articles directly on point dealing with the relationship between patent law and democratic theory. For an excellent discussion of the relationship between scientific discovery and democracy, see KITCHER, supra note 157 , at $114-16$. 
game, the law functions not to punish copying, but to create a set of rules within which participants will act optimally because they are assured that others will reciprocate. By assuring reciprocity, a well-regulated marketplace will develop. The regulatory view recognizes that by promoting reciprocity, patents enable the market to function more efficiently. The assurance game, therefore, offers flexibility in capturing the different uses and contexts of patent law.

To summarize, I propose an alternative to the patent bargain metaphor that is grounded in social contract theory as an interpretation of the patent statute. In Parts III and IV, respectively, I suggest how the model of the assurance game relates to several prominent theories of patent law and how recognizing patent law as a mechanism for creating the wellregulated marketplace can shape our understanding of patent policy and reform.

\section{THE ASSURANCE GAME AND THE MANY FACES OF PATENT LAW}

Patent law should be understood not in terms of a quid pro quo, which rests on social contract theory, but in terms of regulating primary behavior that can be described by the assurance game. To clarify this thesis, I discuss how my argument compares with established theories of patent law. I focus on four main theories: (1) patents as a tool of economic prospecting; (2) patents as a tool for minimizing information costs; (3) patents as a business asset; and (4) patents as a tool of industry regulation. This Part demonstrates some of the limitations of these competing theories of patent law and suggests how the regulatory theory of patent law addresses the limitations.

\section{A. Patents and Prospecting}

Prospect theory understands patent law as a tool for the marketing of inventions. The theory, however, rests on questionable assumptions about the behavior of inventors and about the relationship between commercialization and social interests. The assurance game model addresses these two criticisms of prospect theory by focusing our attention on patent law's role in regulating private orderings to promote market integrity.

The prospecting justification for patents has its origins in Professor Ed Kitch's seminal 1977 article, which presented the theory's basic structure. ${ }^{186}$ The theory has witnessed a revival with the recent scholarship of

186. See Edmund W. Kitch, The Nature and Function of the Patent System, 20 J.L. \& Econ. 265, 267-71 (1977). 
Professor Scott Kieff. ${ }^{187}$ The prospecting theory posits that patents are needed to protect property rights in new inventions for the same reason that property rights are justified in oil, gas, and minerals: to create proper incentives for the discovery and marketing of resources. ${ }^{188}$ Absent strong property rights, new inventions will not be efficiently brought to market and to the public domain upon expiration of the patent right. Derived from the theoretical work of economist Harold Demsetz, ${ }^{189}$ prospect theory has much in common with the social contract theory of patents. Both tend to support strong patent protection as a means of preventing the harms of unauthorized imitation. Both see property rights as a way of solving collective action problems as represented by the prisoners' dilemma. However, prospect theory is not necessarily tethered to the patent bargain metaphor. Kitch's ideas sometimes seem to be grounded in a natural rights view of patents even though he mostly presents himself as a utilitarian. ${ }^{190}$ Professor Kieff presents his own viewpoint as pragmatic, criticizing nonutilitarian theories as missing the realities of the inventive and market processes. ${ }^{191}$ Although he states that patent law is undoubtedly "economic," Professor Kieff does not adopt any formal economic model of patenting and, without examining what primary behavior patent law seeks to regulate, instead takes as a given that patenting exists for commercialization. ${ }^{192}$

There are many familiar criticisms of prospect theory. Two of these criticisms follow from the assurance game. The first are criticisms of prospect theory's underlying behavioral assumptions. The second are criticisms of prospect theory's view of markets and commercialization.

Prospect theory relies upon a particularly risk averse conception of the inventor who requires the protection of strong property rights sanctioned by the legislature and made credible by the courts. To see this point, note

187. See Kieff, supra note 141 , at 65-67 (developing a commercialization theory of patent law from Kitschian prospect theory); F. Scott Kieff, Facilitating Scientific Research: Intellectual Property Rights and the Norms of Science-A Response to Rai and Eisenberg, 95 Nw. U. L. REV. 691 (2001) [hereinafter Kieff, Facilitating]; F. Scott Kieff, Property Rights and Property Rules for Commercializing Inventions, 85 MINN. L. REV. 697 (2001) [hereinafter Kieff, Property Rights].

188. See Burk \& Lemley, supra note 45 , at $1600-01$ (pointing out relationship between prospect theory and property rights theory); Kitch, supra note 186, at 271-75.

189. See Harold Demsetz, Toward a Theory of Property Rights, 57 AM. ECON. REV. 347,348 (1967).

190. See Kitch, supra note 186, at 275-76 (assessing patent law in terms of effects on social welfare maximization).

191. See Kieff, Property Rights, supra note 187, at 707-12.

192. See id. at 747-51. 
that the prospect theory seems to reject the utilitarian view of patent law as developed by Harsanyi's view of the social contract. True utilitarianism would devise laws with consideration of all the relevant interests in society. Recall that Harsanyi's state of nature consists of individuals recognizing they could be anyone in society. ${ }^{193}$ From the perspective of patent law, the relevant interests include pioneer inventors, follow-on inventors, marketers, consumers, and the innumerable other interests reflected in the research and development processes. ${ }^{194}$ Since a person in the natural state could rationally expect to be any one of these parties, patent law ideally would attempt to balance these various interests. Prospect theory, on the other hand, seeks to maximize only the interest of the inventor who is threatened by easy imitation in a non-proprietary marketplace. Prospect theory views the inventor as potential victim of a harm that only strong property rights can protect. As a result, the inventor is depicted as highly risk averse, needing the social insurance of patent law to protect investments in research, development, and marketing. ${ }^{195}$ This assumption is not only a particularly narrow view of inventorship but also an empirically implausible one given the evidence of risk loving behavior among inventors. ${ }^{196}$ Prospect theory should be rejected because of its tacit assumptions about the behavior of inventors and about the terms of the social contract.

Second, prospect theory rests on the unquestioned assumption that what is good for the market is necessarily good for society. The emphasis on commercialization illustrates one part of this fallacy. A patent gives the patentee the right to exclude others from using, making, or selling the invention for a given period of time. This right to exclude can certainly be useful for commercialization, but what prospect theorists fail to recognize is that it can also be useful to prevent commercialization. This is illustrated by the controversy over the rejected patent application for a transgenic organism, or chimera, which combines human and animal cells. ${ }^{197}$ The patent applicants for the chimera were seeking not to commercialize the invention but to prevent the development and marketing of morally questionable life forms. ${ }^{198}$ Prospect theory assumes that the interests against commercialization can accurately express their wishes in the mar-

193. See supra notes 65-70 and accompanying text.

194. For a discussion of the interest groups affected by patent law, see LANDES \& POSNER, supra note 86 , at $412-15$.

195. See Kieff, supra note 141, at $62-63$ (describing the implications of risk aversion and information asymmetries for prospect theory and rent dissipation).

196. See Scherer, supra note 74.

197. Mark Dowie, Gods and Monsters, MOTHER JONES, Jan./Feb. 2004, http://www. online.sfsu.edu/ rone/GEessays/chimerapatent.htm.

198. Id. 
ketplace. ${ }^{199}$ According to prospect theory, if a set of interests does not want to see commercialization, then they must aggregate their resources and buy the patent back from the patentee. If they cannot do so and, therefore, lose to those who want commercialization, then society has spoken and from a utilitarian standpoint, society is better off with commercialization than without. But the flaw in this style of argument should be familiar. To say that noncommercial interests can simply purchase the right from the patentee does not explain the correctness of the market mechanism, but assumes it. ${ }^{200}$ My point is not to reject or denigrate the commercial objectives of patent owners, but to demonstrate the flaw in defenses of the patent system that are based on a fairly simplistic moral view of the marketplace as the ultimate arbiter of policy.

Furthermore, prospect theory assumes that strong property rights are required to ensure an efficient market because strong property rights allow individuals to appropriate market surplus and secure their interest in the marketplace. Since markets function through the pursuit of self-interest, prospect theorists reason, the creation of strong property rights provide the basis for a well-functioning market. ${ }^{201}$ The flaw in this reasoning arises from equating the pursuit of self-interest with strong property rights and the appropriation of surplus. Economic theory, whether in the writings of Adam Smith or in the mathematical theories of Kenneth Arrow and Gerard Debreu, requires that individuals behave in a way to maximize their preferences given their available resources. ${ }^{202}$ This maximization can result in the maximization of social welfare, but only under certain highly

199. See Kieff, Facilitating, supra note 187, at 699-701 (presenting argument that patent law's normative basis is promotion of commercialization rather than promotion of scientific research norms); see also Kieff, Property Rights, supra note 187, at 736-47 (understanding design of patent law in terms of commercialization). But see Bagley, supra note 143, at 710 (identifying noncommercial interests in patent law); Arti Rai, Evolving Scientific Norms and Intellectual Property Rights: A Reply to Kieff, 95 Nw. U. L. REV. 707, 711-12 (2001) (responding to Kieff by showing that too strong patent rights may actually inhibit development).

200. See Margaret J. Radin, Contested Commodities 46-53 (1996) (identifying problems of demarcating a market domain).

201. See Kenneth J. Arrow, The Property Rights Doctrine and Demand Revelation Under Incomplete Information, in ECONOMICS AND HUMAN WELFARE: ESSAYS IN HONOR OF TIBOR SCITOVSKY 23, 29-31 (Michael J. Boskin ed., 1979), reprinted in 4 Kenneth J. Arrow, COLLECTED PAPERS OF KENNETH J. ARROW: THE ECONOMICS OF INFORMATION 216, 222-24 (1984) (describing how lawyers and economists differ in conception of property).

202. See CAMPBELL, supra note 62, at 20-21 (summarizing economic literature on market theory and equilibrium). 
technical and special conditions. ${ }^{203}$ One set of conditions is the absence of externalities that can be assured through the creation of property rights. Nothing in the definition of preferences, resources, or property rights specifies exactly which strong property rights are necessary to ensure efficiency. ${ }^{204}$ In fact, there are multiple efficient outcomes. ${ }^{205}$ Certainly strong property rights can lead to an efficient market outcome if they are defined in a way consistent with the assumptions for a competitive market. ${ }^{206} \mathrm{But}$, so could many other configurations of property rights and market organizations. Prospect theorists confuse the inventor's pursuit of self-interest with the inventor's appropriation of all the market surplus through strong property rights. The former is what is required for market efficiency, ${ }^{207}$ but market efficiency is entirely possible without the latter. ${ }^{208}$

The assurance game model, like prospect theory, also emphasizes the relationship between patents and the market. But unlike prospect theory, the assurance game model does not see patents solely as a tool for commercialization. Instead, the assurance game views patent law as resolving the private ordering problems that arise in the invention process. In this role, patent law resolves these problems by facilitating reciprocity and assurance in the processes of invention and dissemination. Within this conception of the purpose of patents, the intellectual property regime is regulatory and not a tool for the protection of private property. As a consequence, patent law can be understood as an important component of the regulatory state ensuring a well-regulated marketplace.

\section{B. Patents and Information Costs}

Patents are useful in resolving a fundamental externality problem raised by information-based goods. ${ }^{209}$ If a party wants to sell an invention

203. See id. at 21 (discussing pareto optimality and efficiency).

204. See Harold Demsetz, OWNERShIP, CONTROL AND THE FIRM: THE ORGANIZATION OF ECONOMIC ACTIVITY VOLUME I, at 106-07 (1988) (describing property rights as evolving in response to changes in technology and the nature of externalities rather than fixed).

205. See CAMPBELL, supra note 62, at 24 (describing contract curve as describing the potential set of equilibria that can be reached by a market mechanism depending upon the initial allocation of property rights).

206. See id. at 23 (discussing externality problem and property rights).

207. See HIRSCHMAN, supra note 51, at 18-19 (discussing economist's notion of selfinterest as means of coordinating passions such as greed and envy).

208. Cf. Lemley, supra note 14 , at $148-49$ (pointing out that commercialization advocates assume a particular vision of the marketplace rather than focusing on the structure of private orderings).

209. See Long, supra note 158; Clarissa Long, Patent Signals, 69 U. CHI. L. REV. 625 (2002). 
to a second party, the second party typically desires information about the invention. But the first party may not be able to provide the necessary information without revealing the invention, and thereby obviating the need for the second party to buy. This problem of revelation and appropriation is the classic justification for some form of intellectual property right that permits adequate disclosure for the second party while protecting the first party from misappropriation. What form should this intellectual property right should take? A possible answer to this question, in keeping with the general approach to the externality problem, is to design the right to minimize the transaction costs that arise in the marketing of inventions. The specific transaction cost that has received recent attention is the cost of information. Thus, the information cost justification states that patent law is designed to minimize information costs that typically arise in transactions involving innovative activity. ${ }^{210}$

One example of this justification is firms' use of patents as signals to distinguish themselves as worthy of investment by venture capitalists. ${ }^{211}$ Under this theory, patents, in contrast with trade secrets and copyrights, are acquired to show potential investors that an individual or a company has valuable assets and know-how. Like college degrees, patents are a signal of ability in a market where simple revelation of ability is not credible because everyone can make the same claim. ${ }^{212}$ The patent office serves to act as an efficient screen that ensures that the patents go to the correct inventors. ${ }^{213}$ Recent work has extended this theory to explain the value of information disclosure and to distinguish patents from copyrights and other forms of intellectual property in terms of their differential ability to minimize information costs. ${ }^{214}$

Information cost theory does not conclude that patents represent an exchange of exclusivity for progress. In fact, the theory does not have much to say about the duration of exclusivity. Perpetual or infinitely renewable rights would still be consistent with the theory. By distancing itself from social contract theory, information cost theory moves towards the regulatory theory that I am advocating. However, information cost theory is very

210. See Long, supra note 158 , at 471.

211. See Long, supra note 209, at 630; see also KORNBERG, supra note 151, at 234; CYNTHIA RoBbins-Roth, From AlChEMY TO IPO: THE BusINESS OF BIOTECHNOLOGY 155-60 (2000) (discussing venture capital in biotechnology).

212. See MiChael SPEnCE, MARKet Signaling 38-42 (1974) (example of college degrees as signals).

213. See Long, supra note 209, at 632.

214. See Long, supra note 158 , at 504-12. 
different from my regulatory theory of patents because it essentially justifies patents in property terms such as notice and ownership.

Consider why minimizing information costs is important for patent law. The obvious parallel in answering this question is trademark law. Trademarks are classically defended as a tool for minimizing the consumer search costs consumers for products and services. ${ }^{215}$ Consumers can rely on product quality and business goodwill when they make purchase decisions based on brand identifiers. These same identifiers also allow consumers to easily avoid buying products that have failed to maintain certain quality standards. This classic justification has been the subject of criticism, but it does serve as a useful benchmark for interpreting trademark law. ${ }^{216}$ It also serves as a way to understand the information cost justification for patent law. If patents are designed to minimize information costs, the relevant question is with whose information costs patent law should be concerned. Patent law is not concerned about the same consumer as trademark law. In the latter, the typical consumer, based on case law, is the retail shopper who may inadvertently buy the wrong set of tires, laundry detergent, or cereal. In theory, the trademark consumer probably would also include the retailer who must be assured about buying from the correct wholesaler. Patent law is not about the ordinary consumer even though the subject of patent law will sometimes be typical consumer durables. Instead, patent law is about the user of innovative processes, machines, manufactures, and compositions of matter. Such a user may be the end user, but more often it will be the follow-on inventor, the manufacturer, or another party involved with the supply-side of the economy, such as the venture capitalist discussed above. These groups are the principal direct beneficiaries of the new inventions and the parties whose information costs are relevant for patent law.

Once we have identified the relevant parties, we must identify what types of information are relevant, in particular, the relevant transactions whose costs we are trying to minimize. Since the focus on information costs is motivated by a concern with transaction cost minimization, it is not surprising that information cost theory of patents is essentially a property theory. ${ }^{217}$ Therefore, much of information cost theory as applied to patents can be understood as analogies to real property. Many real prop-

215. See LANDES \& POSNER, supra note 86 , at 166-170.

216. See, e.g., Ann Bartow, Likelihood of Confusion, 41 SAN Diego L. REV. 721 (2004).

217. See Yoram BARzel, Economic AnAlysis of Property RIGHTS 4 (1997) (pointing out that questions of transaction costs are intimately related to those of property rights). 
erty rules are designed to minimize the costs of transactions involving land. ${ }^{218}$ Nuisance and trespass law deal with claims regarding conflicting use and ownership of property. Priority rules deal with conflicting claims over title. ${ }^{219}$ Rules about legal description and recording address problems involving transfer of title. ${ }^{220}$ Similarly, according to the information cost theory, patent law is designed to minimize the transaction costs associated with new inventions by focusing on the information relevant to parties who acquire and use inventions. Under this view, patent law is ultimately about minimizing the transaction costs associated with licensing or other transfers of title in the patented invention. ${ }^{221}$

However, this view ignores the role of patent law in regulating inventive activity. The information cost explanation of patent addresses the situation of an inventor deciding upon what projects to expend effort. An inventor in such a situation would look to the information-conveying aspect of patent law to determine what has already been patented and what is in the public domain. But the information cost justification does not help to explain doctrines that relate to the inventive process. Hence, it fails to fully account for the incentive rationale of patent law. For example, the information cost theory would suggest that independent invention should be a defense. The lack of such a defense in patent law is problematic for the information cost theory. ${ }^{222}$ One explanation for this lack is that patent law cares about constructive notice rather than actual notice because of the standardized nature of patented goods. ${ }^{223}$ But, this explanation reduces this inventive dilemma to a property explanation that rests on the underlying place of patents in transactions rather than on any discussion of the inventive process itself.

The assurance game and information cost theory are similar in their emphasis on information. For the assurance game, the key problem is the players' belief that others will act reciprocally. For information cost theory, the key problem is minimizing the costs of acquiring and processing information about inventions. However, a key difference between the two is that information cost theory is about discrete transactions; it is concerned with the ideal patent transaction as analogue to the ideal real estate

218. See Thomas W. Merrill \& Henry E. Smith, Optimal Standardization in the Law of Property: The Numerus Clausus Principle, 110 YALE L.J. 1, 40-42 (2000).

219. See LANDES \& POSNER, supra note 86, at 12-16; Merrill \& Smith, supra note 218 , at $40-42$.

220. See LANDES \& POSNER, supra note 86, at 14.

221. See Long, supra note 158 , at 496-99.

222. See id. at 525-33.

223. See id. at 531-32. 
transaction. The assurance game is concerned with the broader processes of invention and marketing. To illustrate this difference, consider the problem of the independent invention defense. For information cost theory, the lack of an independent invention defense must be explained by claiming that the standardized nature of patent transactions require a rule of constructive notice rather than actual notice. ${ }^{224}$ Under the assurance game, the lack of an independent invention defense can be more simply explained by noting that patent law is regulation of inventive activity concerned with the discovery of functional, standardized products and processes. ${ }^{225}$

The lack of an independent invention defense assures the players that the first inventor will have priority in the invention. As a result, inventors will focus on deriving solutions to unsolved problems within the relevant inventive community. By way of contrast, an independent creation defense exists in copyright because copyright's domain is expressive activity with the primary objective of individual, original expression. In other words, copyright regulates authentic, individual expression while patent regulates the activities of an inventive community. The main difference between information cost theory and the regulatory approach is that the former focuses on discrete transactions while the latter, as guided by the assurance game, focuses on inventive and market processes.

The information cost theory is an important step towards a regulatory theory of patent law, but it falls short, however, in its focus on discrete transactions in inventions modeled on real property. Despite its nuances, information cost theory is essentially a more sophisticated version of prospecting theory. The assurance game model shares with information cost theory its emphasis on information, but does not limit its focus to discrete transactions. Instead, by emphasizing market integrity, the regulatory theory I am advocating focuses on the process of invention as well as the transactional aspect of inventorship.

\section{Patents as a Business Asset}

A third understanding of patent law that is gaining some currency combines elements of prospecting theory with elements of information cost theory. The business asset view of patents identifies the functions of patents as defining property rights within a business entity. ${ }^{226}$ According to this view, patents serve two primary functions. First, patents facilitate

224. See id.

225. See Jaap H. Spoor, Standardization and Exclusivity in Intellectual Property, in INFORMATION LAW TOWARD THE 21 ST CENTURY 374, 374 (1992).

226. See Paul J. Heald, A Transactions Cost Theory of Patent Law (Apr. 28, 2003), at http://papers.ssrn.com/sol3/papers.cfm?abstract_id=385841. 
efficient asset partitioning by creating boundaries between internal firm assets owned by the firm as an entity and external assets owned by themanagers and owners of the entity. ${ }^{227}$ Second, patents resolve problems of rewarding team effort by clearly defining boundaries over the outputs of actors within a firm. ${ }^{228}$ This third theory shares with prospecting theory an emphasis on the commercial exploitation of patents. But instead of concluding that patent rights need to be strong, the business asset view emphasizes the role of patents in resolving certain information problems within firms. The emphasis on information is what the business asset view shares with information cost theory.

As a hybrid of the two previously discussed theories, the business asset view of patents is subject to similar criticisms. The approach emphasizes the commercial value of patents and ignores noncommercial interests that are affected by patent law. Furthermore, the theory emphasizes the postinventive phase of patents and seemingly ignores the role of patents in stimulating invention. Instead, the theory states that patents are a form of business property that businesses acquire to resolve information problems within the firm. Unlike information cost theory, the business asset view takes a much narrower tack to understanding patents by focusing on the information problems facing creditors, managers, and workers in assembling, measuring, and controlling assets. Because of this narrower focus, the business asset approach offers a modest theory of patent law, one that explains patenting behavior by firms and the relationship between patenting decisions and other business decisions. Consequently, business asset theory could be understood as addressing a narrow subset of patent law issues, rather than providing a general theory to guide patent policy.

Despite its narrow focus, the business asset view points in a positive direction in understanding patents. The view does not rely on and, in some ways, rejects the prisoners' dilemma and its unrealistic assumption about private orderings. Reciprocity informs business asset theory, particularly in its recognition of team production problems. ${ }^{229}$ Furthermore, the theory sees uses for patent rights beyond preventing unauthorized imitation and, instead, identifies several functions of patents in regulating business relationships. ${ }^{230}$ I would classify the business asset view of patents as a regulatory theory because it views patent law as regulating primary behavior to

227. See id. at 7.

228. See id. at 17.

229. See id. at 22-24 (using theory to understand university and industry collaborations).

230. See id. at 34 (describing how business asset theory explains value enhancing role of patents for business transactions). 
facilitate certain market and nonmarket relationships. The primary behaviors the approach considers include debtor-creditor relationships, management of business and financial assets, and employment relationships in team production. ${ }^{231}$ Patents serve to regulate various dimensions of these three basic business relationships.

The problem, however, with the business asset view as a regulatory theory is that it fails to consider several salient facts about patents. For example, the business asset view does not explain why we have requirements beyond that of disclosure and written description. ${ }^{232}$ If the purpose of patents is only to establish clear boundaries, why do we need any administrative review for novelty and nonobviousness? The Patent and Trademark Office's (PTO) role, under the business asset view, would be similar to that of the Securities Exchange Commission: to ensure that the firm accurately and sufficiently describes the asset. ${ }^{233}$ Furthermore, the purpose of patent litigation would be largely to police the boundaries between assets much like trespass law in real property. ${ }^{234}$ For the business asset view, patents serve the primary - and perhaps exclusive - function of creating a reliable system of title, and patent law is a means of regulating property claims. ${ }^{235}$ Consequently, the business asset view would treat patents in the same way as the prospecting and information cost theories, which should not be surprising because it is a hybrid of the two approaches.

The problem, in summary, is that while business asset theory does recognize a patent's role in regulating conduct, the theory ignores the processes of invention and research and development, even though patent law is clearly concerned with these processes given the patent office's requirements of novelty, nonobviousness, and utility. Therefore, the business asset view falls short of providing a theory of patents as regulation. The assurance game model, by contrast, recognizes the role of patent law in regulating primary behavior and incorporates the use of patents as a business asset in the notion of market integrity.

231. See id. at 3 .

232. See id. at $37-40$ (explaining how business asset theory can explain a lack of correlation between strong patent rights and research and development expenditure after the creation of the Federal Circuit but offering little explanation for other patent puzzles).

233. See id. at 38 (focusing on communicative and descriptive value of patents).

234. See id. at 39 (questioning criticisms of the U.S. Patent and Trademark Office in issuing invalid patents).

235. See id. at 40 (explicitly describing patents as a title registration system). 


\section{Patents and Industry Regulation}

Professors Dan Burk and Mark Lemley's article on the patent law as industry- and technology-specific regulation is an example of my proposal for a regulatory view of patents. ${ }^{236}$ Their work shows how the Federal Circuit has tailored patent rules to various industries such as biotechnology and software and analyze how the tailoring affects invention and innovation. ${ }^{237}$ Essentially, they identify a common law of patents that applies general patent doctrines to the specific facts raised by different industries and technologies. ${ }^{238}$ Their goal is to rationalize the common law of patents to be more sensitive to the problems posed by particular technologies and confronted by industry players in the innovation process. By focusing on patent law as common law, however, the authors de-emphasize the role of the PTO in shaping industry-specific policy. ${ }^{239}$ Perhaps this choice reflects the nature of the PTO, whose rulemaking authority is very different from that of other agencies such as the Environmental Protection Agency or even the Copyright Office. ${ }^{240}$

More likely, the common law of patent reflects the relative balance of lawmaking power between the PTO and the Federal Circuit, the latter being the final adjudicator over PTO legal and factual findings. ${ }^{241}$ Regardless of the reason, Professors Burk and Lemley present a regulatory view of patent law modeled on common law adjudication which downplays the role of agencies.

Professors Burk and Lemley's case for industry-specific patent law starts with identifying five principal problems for defining property rights

236. See Burk \& Lemley, supra note 45.

237. See id. at 1589-95.

238. See id. at 1696 (discussing development of a general theory of how "court might tailor patent law to the need of specific industries"). For a criticism of what is described as "macro-ex exceptionalism," see R. Polk Wagner, Of Patents and Path Dependency: $A$ Comment on Burk and Lemley, 18 BERKELEY TECH. L.J. 1341, 1351-56 (2003) (arguing that technology-specific patent law is an obvious result of the structure of patent law and questioning the desirability of a sector-specific patent law).

239. Cf. Lemley, supra note 139, at 1497-00 (questioning efficacy of increasing funding of PTO given how few patents actually are licensed or litigated).

240. Cf. Karen Hauda, Remarks at the Meeting of the President's Council on Bioethics, Session 5, Regulation 3: Patentability of Human Organisms 1, History and Current Law (June 20,2002) (stating that PTO lacks substantive rule making authority), available at http://www.bioethics.gov/transcripts/jun02/jun21session5.html. Section 702 of the Copyright Act vests rule-making authority in the Register of Copyrights. See 15 U.S.C. $\S 702(2000)$.

241. See, e.g., Kerr, supra note 131, at 140-41; Nard, supra note 131, at 1416-23. 
over the innovation process. ${ }^{242}$ The first problem is creating proper incentives for commercializing innovation. This overlaps with the prospecting theory of patents. ${ }^{243}$ The second problem is identifying the proper relationship between competition and innovation. This follows from the uncertainty over what type of markets, monopolistic or competitive, best promotes technological change. ${ }^{244}$ The third problem, related to the second, is defining the nature of cumulative innovation and the possible barriers to innovation created by too strong a property right. ${ }^{245}$ The fourth and fifth problems have to do with the proper scope of the patent right. If property rights are too narrow and are divided among too many private owners, the problem is that of the anticommons. ${ }^{246}$ If property rights are too broad and patents owned by different private parties overlap, the problem is that of patent thickets. ${ }^{247}$ Professors Burk and Lemley demonstrate that these problems vary across industries and technologies. ${ }^{248}$ They also identify specific policy instruments within patent law, such as the doctrine of nonobviousness and the written description requirement, which can be modulated to deal with these five problems. ${ }^{249}$ They conclude by showing how patent law should be tailored to deal with the unique problems facing different industries.

Other areas of the law that are largely driven by adjudication are also industry specific. Contract law, while consisting of general principles, also varies based on subject matter. ${ }^{250}$ For example, special rules exist for real estate contracts, service contracts, and insurance contracts. ${ }^{251}$ Some of these special rules reflect statutory developments, as with insurance, but more often the rules result from application of general rules to idiosyncratic fact patterns that are canonical for a particular class of contract. The same case can be made for tort law with its multiple subspecialties such as medical malpractice, liability for defective products, and liability for de-

242. See Burk \& Lemley, supra note 45 at $1596-1600$.

243. See id. at 1600-04.

244. See id. at 1604-07.

245. See id. at 1607-10.

246. See id. at 1610-14.

247. See id. at 1614-15.

248. See id. at 1615-27.

249. See id. at 1638-68.

250. See John P. Esser, Institutionalizing Industry: The Changing Forms of Contract, 21 LAW \& SOC. INQUIRY 593, 595-97 (1996).

251. See, e.g., Hill v. Gateway 2000, Inc., 105 F.3d 1147, 1149 (7th Cir. 1997) (Easterbrook, J.) (describing various types of contracts). 
fective services. ${ }^{252}$ A similar phenomenon occurs in statutory areas of the law. Antitrust law, which can be fully described by sections 1 and 2 of the Sherman Act and section 3 of the Clayton Act, rests heavily on fact finding in particular industries and markets and therefore, results in industryspecific rules. ${ }^{253}$

A good example of industry-specific rules in antitrust is provided by the Microsoft case, where the D.C. Circuit developed a rule of reason approach to tying arrangements applicable to the software industry. ${ }^{254} \mathrm{An}$ other example is provided by court-defined rules for characterizing horizontal agreements as per se illegal. ${ }^{255}$ These rules rest in part on the nature of the agreement but also on the nature of the industry, with fledgling industries and nonprofit markets usually subject to a rule of reason analysis. ${ }^{256}$ Given that most lawmaking occurs through a form of common law adjudication, it would be surprising if patent law did not exhibit differences that could be correlated with specific industries or technologies. ${ }^{257}$

While it is not surprising that patent law is industry-specific as a matter of fact, it does not follow that patent law should be industry-specific as a matter of principle, a point that Professors Burk and Lemley seem to be endorsing. ${ }^{258}$ A narrow version of their conclusion is that since patent law has become industry-specific, the Federal Circuit should be more selfconscious about what it has done and adopt a more rational and systematic approach to developing industry-specific patent law. ${ }^{259}$ That the Federal Circuit should be more self-conscious about what it is doing is perhaps not

252. See, e.g., Stephen Sugarman, A Restatement of Torts, 44 STAN. L. REv. 1163, 1165 (1992) (describing specializations within tort law).

253. See, e.g., Peter C. Carstensen, How to Assess the Impact of Antitrust on the American Economy: Examining History or Theorizing?, 74 IOWA L. REV. 1175, 1181 (1989) (analyzing market specific effects and application of antitrust laws); Reza Debadj, Saving Antitrust, 75 COLUMB. L. REV. 745, 857 (2004) (describing market specific antitrust rules).

254. See United States v. Microsoft Corp., 253 F.3d 34, 89-95 (2001) (holding that per se rule for tying arrangements not appropriate for innovative and dynamic industry like software).

255. See Keith Hylton, Antitrust LAw: Economic TheORy \& COMMON LAW EVOLUTION 104-12 (2003) (describing the division between cases determined under a per se approach and those under a rule of reason).

256. See NCAA v. Bd. of Regents, 463 U.S. 1311 (1983); Broadcast Music, Inc. v. Columbia Broad. Sys., Inc., 439 U.S. 1069 (1979).

257. For a discussion of common law adjudication of a statutory scheme and the role of the courts in applying general legal principles to specific facts, see GUIDO CALABRESI, A COMMON LAW FOR THE AGE OF STATUTES 160-66 (1981).

258. See Burk \& Lemley, supra note 45, at 1696.

259. See id. 
controversial. That it should rationalize and systematize the approach is. The problem is that the authors are assuming that patent policy is a matter for the courts rather than for legislative and administrative bodies. ${ }^{260}$ In antitrust, for example, market-specific rules often become the basis for U.S. Department of Justice and FTC guidelines that serve to correct and guide the court's missteps. ${ }^{261}$ The merger guidelines and the recent guidelines for collaboration among competitors illustrate how common law antitrust policies are complemented by administrative rules that sometimes follow the course set by courts and sometimes veer in a different direction. ${ }^{262}$ Copyright law provides another example. More so than patent, which has a crucial administrative component, copyright law develops almost wholly through adjudication. ${ }^{263}$ Nonetheless, the Copyright Office does pass guidelines to aid adjudication in such areas as fair use and the first sale doctrine. ${ }^{264}$ Furthermore, the industry-specific nature of copyright is reflected directly in the Copyright Act, which contains special rules based upon specific industries, such as retailers or libraries, and specific categories and rules for different types of works, such as pictorial, graphic and sculptural works. ${ }^{265}$ Needless to say, the common law is important as a tool of regulation, but the common law works most often in tandem with administration and legislation. ${ }^{266}$ This point needs to be understood better in devising a system of patent law, especially one that is industry-specific, as Professors Burk and Lemley propose.

While their work on industry-specific and technology-specific patent law is fairly comprehensive, Professors Burk and Lemley's approach is subject to the same "confusion in patent theory" that they raise against other scholars. ${ }^{267}$ They are correct in pointing out that patent theory is het-

260. See Ghosh \& Kesan, supra note 140, at 1260; Wagner, supra note 238, at 1356.

261. See D. Bruce Hoffman \& M. Sean Royall, Administrative Litigation at the FTC: Past, Present, and Future, 71 ANTITRUST L.J. 319, 327-30 (2003) (identifying development of market specific rules in FTC administration of antitrust laws).

262. See Stephen Calkins, Perspectives on State and Federal Antitrust Enforcement, 53 DUKE L.J. 673, 724 (2003) (providing an example of the evolving relationship between common law and statutory antitrust).

263. See, e.g., James Boyle, Intellectual Property Policy Online: A Young Person's Guide, 10 HARV. J.L. \& TECH. 47, 81 (1996); Philip Weiser, Regulatory Challenges and Models of Regulation, 2 J. TELECOMM. \& HIGH TECH. L. 1, 12 (2003).

264. See Jon M. Garon, Normative Copyright: A Conceptual Framework for Copyright Philosophy and Ethics, 88 CORNELL L. REV. 1278, 1342-43 (2003).

265. For a discussion of sector specific copyright law, see MICHAEL W. CARROLL, The Uneasy Case Revisited: A Sectoral approach to Intellectual Property (2003).

266. See CALABRESI, supra note 257 , at 6 .

267. See Burk \& Lemley, supra note 45, at 1596. 
erogeneous and sometimes contradictory. To adapt a bad joke about economists, you could line up patent theorists end to end and never reach a conclusion. Part of this heterogeneity reflects implicit normative assumptions about competition and innovation; part reflects the different approaches of lawyers and economists to the patent problem. ${ }^{268}$ Burk and Lemley provide an invaluable service by trying to synthesize the diverse theories under their own theory of industry- and technology-specific patent law based on common law adjudication. But there is a certain ad hocness to their analysis: their approach is to recognize the multiple goals that the various policy levers of patent law pursue and to tailor these goals to the empirically identified problems facing certain industries.

Tellingly, Burk and Lemley's approach echoes the rhetoric of "industrial policy" that was influential among policy makers in the 1970 s and 1980 s in the United States. ${ }^{269}$ "Industrial policy" was a scheme, modeled roughly on Japanese political economy, to stimulate the growth of specific high-payoff industries through subsidies and other government programs. ${ }^{270}$ Industrial policy was opposed to a deregulatory approach that advocated the cutting of taxes and the loosening of regulation in certain key sectors to promote growth. ${ }^{271}$ A glimpse at U.S. economic policy during the 1980s and 1990s indicates a victory for less intrusive regulatory mechanisms. ${ }^{272}$ While Burk and Lemley do not suggest that their approach will somehow lead to economic growth and development, their industryspecific approach raises the same questions asked of industrial policy: How do we know which industries to target? What shape should these policies take? How long should they last? What institutions should determine these policies? ${ }^{273}$

The current debate within patent law is largely a debate over the proper role of the state in regulating the marketplace. Prospect, information cost, and business asset theories imply a minimalist role for the state, which would be limited to defending patents as property rights and tools for contracting. The industry regulation approach implies a more intrusive

268. See George Priest, What Economists Can Tell Lawyers About Intellectual Property: Comment on Cheung, 8 RES. L. \& ECON. 19, 23 (1986).

269. See William R. Nester, A SHORT History OF AMERICAN INDUSTRIAL Policies 10 (1998).

270. See Jim Chen \& Daniel Gifford, Law as Industrial Policy: Economic Analysis of Law in a New Key, 25 U. Mem. L. Rev. 1315 (1995).

271. See Roger Pilon, On the Folly and Illegitimacy of Industrial Policy, 5 STAN. L. \& POL'Y REV. 103 (1993).

272. See Martha Minow, Partners, Not Rivals 7-22 (2002).

273. See Pilon, supra note 271 , at 113-15 (identifying issues raised by industrial policy proposals). 
role for the state, particularly for the Federal Circuit, in tailoring patent law for the needs of particular industries. The assurance game I propose implies yet another role for the government, one that considers the effect of regulation on behavior and on the choice of equilibrium in society. Under the terms of the assurance game, the government's role is greater than defending property and contract rights and less than regulating industrial policy. The assurance game focuses our attention on two issues. The first is identifying areas where private orderings do not lead to optimal outcomes because of a failure of reciprocity. The second is allocating regulatory power among various institutions: the courts, the legislature, the market and noncommercial institutions. In Part IV, I develop these two points and their implications for patent policy.

\section{IMPLICATIONS FOR PATENT POLICY AND REFORM}

Two central points have been developed in this Article. First, the quid pro quo metaphor in patent law rests on a theory of social contract that has little relevance to the economics and administration of patent law. Second, the regulatory role of patent law was developed as an alternative to the social contract view of patents. This second point was developed through a critique of the prisoners' dilemma and analysis of the assurance game as an alternate description of private orderings that patent law regulates.

In this penultimate part, I advance my argument for the regulatory model of patent law and discuss its implications in three current controversies. The first controversy I discuss is the debate over patentable subject matter, stemming from the seminal case of Diamond v. Chakrabarty, and the argument that subject matter should be limited on grounds of morality and public safety. I argue that the assurance game model serves to understand the issue of morality and to explain Chakrabarty outside the rubric of property. The second topic is the NAS's recommendations for patent reform, which provide the clearest example of the regulatory model of patent law that I espouse. I assess these criteria and recommendations in terms of the assurance game and the broader regulatory model that I have developed in Parts II and III. Finally, I address the FTC's suggestion that patent law should be understood as a form of competition policy. ${ }^{274} \mathrm{I}$ defend the FTC's recommendations as correctly recognizing the important effects of patent law on markets and competition. Separating patent law from market regulation runs the danger of permitting anticompetitive uses of patents that are harmful to both innovation and innovators. A short final

274. See FTC REPORT, supra note 16, Executive Summary, at 2-3. 
subsection summarizes the implications of the assurance game and the regulatory theory of patent law for patent policy and reform.

\section{A. Patentable Subject Matter}

What is potentially patentable under a given patent regime? The problem is not one of patentability, or whether a given invention meets the requirements of novelty, nonobviousness, utility, and enablement, but of whether something qualifies as an invention. ${ }^{275}$ In the United States, this problem implicates both the patent statute and the Constitution, which limits Congress's authority to grant exclusive rights to "inventors" in their "discoveries." "276 Absent constitutional authority, the question would hinge on statutory interpretation, the intent of the legislature, and the language adopted to embody that intent. As a threshold question, patentable subject matter is both illustrative and critical in understanding patent law as a system of regulation as opposed to a quid pro quo grant of exclusivity for progress.

The seminal case on patentable subject matter in the United States is Diamond v. Chakrabarty, the 1980 case that allowed for the patentability of genetically altered organisms. ${ }^{277}$ The Chakrabarty decision laid the groundwork for the often reviled expansion in patentable subject matter over the past decade. The Court endorsed the principle that patent law extends to everything under the sun that is man-made, based on a single sentence from an extensive legislative history. ${ }^{278}$ This principle, based on that single sentence, became the basis in the 1980s and 1990s to extend patent law to include software, a field that had been excluded from patent law by Supreme Court decisions, ${ }^{279}$ and business methods, a gray area in the field of patents since the $1900 \mathrm{~s} .{ }^{280}$ The trivial and "patently absurd" patents for

275. See 35 U.S.C. $\S \S 102,103,112$ (2000). The question of patentable subject matter arises under Section 101 of the Patent Act, which states: "Whoever invents or discovers any new and useful process, machine, manufacture, or composition of matter, or any new and useful improvement thereof, may obtain a patent therefor, subject to the conditions and requirements of this title."

276. U.S. CONST. art. I, $\S 8,1.8$.

277. 447 U.S. 303 (1980). Chakrabarty, a microbiologist, sought a patent for a genetically altered bacterium. $I d$. at 305 . The Supreme Court affirmed a ruling in Chakrabarty's favor from the Court of Claims. Id. at 318.

278. Id. at 308-09.

279. See Julie E. Cohen \& Mark A. Lemley, Patent Scope and Innovation in the Software Industry, 89 CALIF. L. REV. 1, 8-11 (2001).

280. See Robert P. Merges, As Many as Six Impossible Patents Before Breakfast: Property Rights for Business Concepts and Patent System Reform, 14 BERKELEY TECH. L.J. 577, 581-82 (1999). 
such items as a cat hammock, ${ }^{281}$ a peanut butter and jelly sandwich, ${ }^{282}$ and a method of exercising one's cat with a laser pointer, ${ }^{283}$ are arguably the result of the Chakrabarty court's largesse. In fact, the inclusion of life forms within the world of patents is, according to many, a critical step for the propertization of inventive activity, extending the arm of exclusivity to almost all human activity. By a single decision, according to one argument, the Supreme Court turned a host of human creations, from the banal, such as the cat hammock, to the profound, such as genetically altered organisms, into the legal category of property. ${ }^{284}$ This move arguably transformed the trivial into the subject of federally protected rights and life itself into marketable commodities. ${ }^{285}$

It is important to note that Chakrabarty does not use the quid pro quo metaphor. In fact, both the majority and dissent viewed the issues in regulatory terms: both the majority and dissent framed the debate in terms of how Congress structured patent law to regulate primary conduct and technology. ${ }^{286}$ Both the majority and dissent accepted a version of the conclusion that patent law should be technology-neutral. ${ }^{287}$ They disagreed on how to fit the new technology of genetic engineering into the scheme that Congress had adopted. The dissent emphasized the enactment of plantrelated statutes as indicative of how Congress intended to regulate genetically altered life forms. ${ }^{288}$ The majority, on the other hand, pointed to the broad language of the Patent Act itself and the silence within the plantrelated statutes to rule in favor of the technology. ${ }^{289}$ Both the majority and dissent, despite their differences, correctly structured the analysis in terms of regulation rather than property.

From the perspective of the assurance game, the treatment of patentable subject matter as an issue of regulation rather than of property is justified. One criticism of my regulatory interpretation of the majority's opinion is that it ignores the outcome of the Chakrabarty decision in granting exclusive, private rights to a life form. But this criticism confuses what is potentially patentable from what can actually be patented. By ex-

281. U.S. Patent No. 6,209,491 (issued Apr. 3, 2001).

282. U.S. Patent No. 5,567,454 (issued Oct. 22, 1996).

283. U.S. Patent No. 6,701,872 (issued Mar. 9, 2004).

284. See Bagley, supra note 143, at 546; Louis. E. Wolcher, The End of Technology: A Polemic, 79 W ASH. L. REV. 331, 338 (2004).

285. See Wolcher, supra note 284 , at 338-39.

286. Diamond v. Chakrabarty, 447 U.S. $303,308-09,318$ (1980); id. at 318-19

(Brennan, J., dissenting).

287. Id. at 315-16; id. at 321-22 (Brennan, J., dissenting).

288. Id. at 320-22 (Brennan, J., dissenting).

289. Id. at $310-15$. 
panding the scope of subject matter, the Chakrabarty decision brought a wide range of invention and inventive activity within the sunlight of the regulatory system that is patent law. This exposure to regulation is consistent with the implications of the assurance game as analyzed in Part II. While the property models embodied in the prisoners' dilemma regard patent law as prisoners' creating exclusivity, the assurance game views patent law as promoting reciprocity by creating openness and encouraging integrity in the market and other institutions. Arguably, the Chakrabarty decision advanced these precise goals. By bringing a wide range of inventions into the patent system, the decision exposed these inventions to public scrutiny and debate. Contrary to the dissent's argument that the decision usurped democratic decision making over a crucial regulatory function, the majority's decision was an important step in allowing public scrutiny of inventions through the patent system and potentially through other regulatory mechanisms. The dissent's position runs the risk of relegating critical inventions to the realm of secrecy.

The recent controversy over the "sick beagle" patent in the United States provides a useful example of these points. ${ }^{290}$ The University of Texas Health Sciences Center submitted a patent application for a method of infecting a healthy beagle with a strain of a pulmonary disease for research purposes. ${ }^{291}$ The application also included a claim for the resulting animal. ${ }^{292}$ Animal rights activists protested both the University's research activities and the patent application, and because of the public pressure, the University of Texas decided to withdraw its application. ${ }^{293}$ Needless to say, the mere withdrawal of the application may not be sufficient for those who advocate an end to research use of animals. Furthermore, many will be critical of the censorious use of political activism against scientific research. Regardless of individual positions on the political issues, the lesson for patent law is that allowing broad subject matter permitted public debate over the invention. A broad decision like Chakrabarty brings inventions within the purview of regulation and public scrutiny and ultimately can further the goals of science and democracy.

A similar point could be made about business method and other seemingly absurd patents. In 1998, Amazon.com's enforcement of its one-click shopping patent against Barnesandnoble.com brought the public's atten-

290. See generally University Gives Up Patents on Sick Dogs, WaLl ST. J., May 28, 2004 , at B7.

291. Antonio Regalado, Patent on a Sick Dog Challenged, WALl ST. J., Feb 26, 2004, at D5.

292. Id.

293. Id.; University Gives Up Patent on Sick Dogs, supra note 290. 
tion to some of the anticompetitive uses of patents. ${ }^{294}$ Amazon.com eventually lost its suit, and the decision was an impetus for the FTC's 2003 report on patent law and competition policy, discussed below. Once again, my argument here is not that all patents are anticompetitive or that the system needs reform; I address these issues in Section C. Rather, the experience with one-click demonstrates how allowing a broad patentable subject matter stimulates public debate and furthers the goals of patent law as a regulatory system. The case of pharmaceutical patents, explored by myself and other scholars, also illustrates patent as regulation. ${ }^{295}$ Even the expansion and recognition of trivial patents support my argument. The acquisition of trivial patents opens them to public scrutiny and forces us as a society to confront such fundamental questions as what innovation is and what the administrative role of the PTO is, questions that are the focus of the recent NAS report discussed in Section B.

A comparison with the European Patent Office's treatment of patentable subject matter provides further support for the regulatory view of patent law. Under the European Patent Convention, the scope of patentable subject matter is narrower than in the United States. ${ }^{296}$ The Convention expressly excludes "plant or animal varieties" and "essentially biological processes for the production of plants or animals" from patent protection. ${ }^{297}$ The Convention also permits the Patent Office to consider morality and ordre publique (health and safety concerns) in determining patentability. ${ }^{298}$ The interpretation of these limitations and their application to specific technologies has generated litigation and public debate in Europe. ${ }^{299}$ However, the judicial review of these disputes indicates a greater awareness of the regulatory purpose behind patent law. The Technical Board of Appeals within the European Patent Office gives particular attention to the regulatory purpose of patent law and the public policy considerations raised by pursuit of certain lines of scientific inquiry and technological advancement. ${ }^{300}$ Furthermore, the consideration of morality and ordre publique indicates that patent law is more closely intertwined with general health and safety law in Europe than in the United States. ${ }^{301}$ By way of contrast, United States patent law restricts its scope to the identifi-

294. Amazon.com, Inc. v. Barnesandnoble.com, Inc., 239 F.3d 1343 (Fed. Cir. 2001).

295. See supra notes $136-37$ and accompanying text.

296. See supra notes $144-48$ and accompanying text.

297. See supra note 145.

298. See id.

299. See id.

300. See id.

301. See supra notes $144-48$. 
cation and disclosure of valuable inventions, leaving the other regulatory goals of controlling the development and use of harmful technologies to other agencies. ${ }^{302}$

In summary, the broad view of subject matter of patent endorsed by Chakrabarty brings a broad range of inventions within the regulatory domain of patent law. The Chakrabarty decision itself implicitly acknowledged the view of patents as a system of regulation. Furthermore, in contrast with the European system, the U.S. patent system decouples the regulatory function of patent from other exercises of police power. This difference reflects the different regulatory structures of technology in the two systems. It also highlights the differences in the systems' respective judgments about the relative competencies of the patent office and other regulatory bodies.

One important caveat concludes this discussion of patentable subject matter. While the Chakrabarty court appropriately adopted a regulatory view of patents, the Supreme Court recently misstepped in applying the precedent. In its 2001 decision in J.E.M. Ag Supply, Inc. v. Pioneer HiBred International, Inc., the Court addressed a question left open by Chakrabarty: can utility patents be obtained for plants and plant varieties or are the Plant Protection Act and the Plant Variety Protection Act the sole basis for protection? ${ }^{303}$ The majority concluded that utility patents were not precluded by the alternative system for plant protection and reasoned that this conclusion followed inevitably from the Chakrabarty precedent. If, the J.E.M. majority reasoned, the Chakrabarty decision held that patentable subject matter includes everything under the sun that is manmade, then certainly plants and plant varieties have to be included. ${ }^{304}$

The dissenting opinion was more careful its application of precedent. $^{305}$ Examining the regulatory structure created by the plant protection statutes, the dissent reasoned that Congress intended to have a different system with different standards and different regulations to apply to plants than to utility patents. ${ }^{306}$ The dissent concluded that this regulatory structure indicated a clear Congressional intent to exclude plants from the scope of utility patents. ${ }^{307}$ The majority ignored the purposes behind the separate plant protection statutes and the implications of their regulatory

302. See id.

303. 534 U.S. 124 (2001).

304. Id. at 132 .

305. Id. at 148 (Breyer, J., dissenting).

306. Id. at 159 (Breyer, J., dissenting).

307. Id. at 151 (Breyer, J., dissenting). 
structure. ${ }^{308}$ They also ignored the regulatory view of patents implicit in Chakrabarty and appealed instead to the patent bargain metaphor to further broaden the scope of patentable subject matter. ${ }^{309}$ The dissent, however, understood the true lesson of Chakrabarty and followed it appropriately in construing the regulatory system of patent consistently with the regulatory system for plants. ${ }^{310}$ The J.E.M. decision illustrates the conflict in patent law between the social contract metaphor and the regulatory view. A more careful consideration of these conflicting metaphors may have avoided a decision that dramatically altered the regulatory landscape created by Congress. ${ }^{311}$

\section{B. The NAS Study as a Model for Regulatory Patent Law: A Critical Commentary of Agencies and Courts}

In April 2004, the NAS, the research arm of Congress, released a preliminary draft of a report entitled A Patent System for the 21st Century. The report offered detailed suggestions for patent reform, and while I do not agree with all the details, the assumption of the report is consistent with the regulatory view of patent law advocated in this Article. The NAS did not present patent law as a quid pro quo or use the language of social contract. Instead, it presented patent law as a means of regulating primary conduct in the innovation process. ${ }^{312}$ After describing the report's recommendations and criteria for evaluating a patent system, I address three points from the report that help to structure a regulatory patent law: (1) balancing the role of agencies and courts in regulating the innovation process; (2) reforming current patent doctrines, such as nonobviousness, within a regulatory framework; and (3) creating regulatory institutions for the administration of patent law consistent with democratic governance.

The NAS report recommended seven reform measures to improve the existing patent system: (i) preserving an open-ended, unitary, and flexible patent system that accommodates new technologies within a consistent framework that can be adapted to different industries and technologies; (ii) strengthening the nonobviousness standard to raise the level of patent quality and to create incentives for research and development in innovative and value-added areas; (iii) instituting an open review procedure; (iv) expanding the financial and manpower resources of the PTO; (v) reinvigo-

308. Id. at $141-42$.

309. Id. at 144 .

310. Id. at 149-150 (Breyer, J., dissenting).

311. See Dennis J. Karjala, Distinguishing Patent and Copyright Subject Matter, 35 CONN. L. REV. 439, 446 n.26 (2003); Rai, supra note 139, at 1135 n.389.

312. See NAS STUDY, supra note 15 , at 19. 
rating doctrines, like experimental use, to shield research uses of patented inventions from liability; (vi) making patent litigation more predictable by removing subjective and manipulable elements from litigation; and (vii) harmonizing patent law internationally. ${ }^{313}$ These seven proposals can be divided into procedural and substantive reforms. Proposals (iii), (iv), and (vii) are procedural; each attempts to correct the manner in which the patent system is administered. The remaining proposals attempt to alter substantive doctrines that currently hinder the efficacy of the patent system. These proposals, both substantive and procedural, were drafted with the aid of law scholars, economists, and research scientists. In fact, an overarching reform initiative that the NAS emphasized is the incorporation of input from a wide range of expertise and interests in designing patent law.

Although the report is not explicitly normative, there are several normative foundations for the reform proposals. The NAS saw the patent system as a key ingredient for technological innovation and economic growth. These normative foundations are described in the report as seven criteria for gauging a patent system. ${ }^{314}$ These stated criteria reflect the input of legal and economic scholars as well as researchers into the review process. The criteria are, on the one hand, unsurprising and, on the other, somewhat baroque as a basis for reform. For example, the call for harmonization in criterion six begs the question of what rule should be the basis for integration. The report points to the need to harmonize the United States's first-to-invent system with the rest of the world's first-to-file system. Presumably, transaction costs may be lower if the United States conformed to the rest of the world. ${ }^{315}$ This conclusion ignores some of the benefits of a first-to-invent system over a first-to-file system; the former

313. Id at 4-7.

3.14. The seven criteria are: (i) The patent system should accommodate new technologies; (ii) The system should reward only those inventions that meet the statutory tests of novelty and utility that would not, at the time they were made, be obvious to people skilled in the respective technologies, and that are adequately described; (iii) The patent system should serve its second function of disseminating technical information; (iv) Administrative and judicial decisions entailed in the patent system should be timely, and the costs associated with them should be reasonable and proportionate; (v) Access to patented technologies is important in research and in the development of cumulative technologies, where one advance builds upon one or several previous advances; (vi) Greater integration of or reciprocity among the three major patents systems (i.e. Europe, Japan and the United States) would reduce public and private transaction costs, facilitating trade, investment, and innovation; (vii) There should be a level playing field, with intellectual property rights holders who are similarly situated enjoying the same benefits while being subject to the same obligations. Id. at 41-42.

315. See Mark A. Lemley \& Colleen Chien, Are the U.S. Patent Priority Rules Really Necessary?, 54 HASTINGS L.J. 1299, 1304-05 (2003). 
encourages a race to invent while the latter creates a race to the patent office that may inefficiently shift resources away from research and development. The criteria, however, are consistent with many of the themes emphasized by legal scholars writing about patent reform and, therefore, warrant attention from the scholarly community. ${ }^{316}$

Although the report referred to patents as a reward for innovation, the drafters otherwise eschewed describing the patent grant in terms of a social contract. Instead, the drafters presented a regulatory view of patent law that governs primary behavior in the innovation process. Patent reform is framed partly in terms of institutional reform, specifically the balance between courts and agencies, and partly in terms of the effect of doctrine on behavior, specifically the impact of doctrines like experimental use on research activities. But while the regulatory perspective is laudable, the lack of a coherent framework is troubling. The assurance game analyzed in Part II provides a helpful framework to fill the gap. The model of the assurance game suggests that patents are not simply a form of property necessary to protect against copying or secrecy. Instead, under the terms of the assurance game, patent law should be designed to assure reciprocity and promote trust and assurance in market and other institutions. These instrumental goals of patent law aid in interpreting the NAS's three key regulatory proposals: (1) balancing the role of agencies and courts in regulating the innovation process; (2) reforming current patent doctrines, such as non-obviousness, within a regulatory framework; and (3) creating regulatory institutions for the administration of patent law consistent with democratic governance.

Several of the NAS proposals would restructure the relationship between the courts and the PTO in patent administration and litigation. ${ }^{317}$ Through these proposals, the NAS called for a strengthening of the resources of the PTO, an openness to patent prosecution to allow opposition from those who seek to challenge an application, and a streamlining of patent litigation. ${ }^{318}$ If all these proposals were implemented, the patent system would allegedly serve to balance the needs of the inventor in protecting his rights in the invention with the needs of users in having access to the invention for research purposes. Implicit in these proposals is a shift

316. See, e.g., Burk \& Lemley, supra note 45 at 1596-99 (describing normative heterogeneity of patent law theory with emphasis on commercialization and commons theories); Jay P. Kesan, Carrots and Sticks to Create a Better Patent System, 17 BERKELEY TECH. L.J. 763, 767-69 (2002) (focusing on two normative goals, the preservation of patent quality and the prevention of opportunistic behavior, in designing patent law).

317. Proposals (i), (iii), (iv), and (vi) specifically.

318. NAS STUDY, supra note 15 , at $95-108,117-23$. 
in administrative authority from the courts to the agency. Such a shift is motivated by both the Patent Office's expertise as a finder of fact in technically complex and specialized areas as compared to judges and also by the cost of litigation as compared to prosecution. Some scholars have questioned this presumption, arguing that since so few patents are ever litigated, shifting patent administration towards agencies may not really be efficient. ${ }^{319}$ These same scholars call for greater emphasis on litigation to identify bad patents and to police patent enforcement. ${ }^{320}$

I have responded to the pro-litigation argument in two ways in a separate article. ${ }^{321}$ First, the fact that so few patents are actually commercialized indicates the low quality of granted patents and the ease with which patents can be obtained. ${ }^{322}$ If the PTO was performing effectively, relatively few patents would go unexploited. The agency's role is to grant patents to deserving inventions, ones that licensors would want to access. The lack of commercialization may be evidence that the agency is acting as an inefficient screen of patents. Second, the screening role of the agency cannot be overemphasized. ${ }^{323}$ Given the types of information problems that arise in innovation markets-problems that may make it difficult to realize reciprocity-the PTO needs to be proactive in policing patent quality as efficiently as possible. As I have stated elsewhere, the scholars who are skeptical of the PTO implicitly advocate a registration system for patents without acknowledging the problems of such a system. The assurance game formalizes these two arguments by demonstrating the need to structure a patent system that promotes reciprocity and trust. The NAS's proposal to shift administration towards the agency level is consistent with the prescription of the assurance game.

The shift to a greater role for the agency is also consistent with the call for clarifying patentability doctrines, such as nonobviousness, and the push towards more open patent review processes, such as an opposition system. Implicit in the proposal for strengthening the nonobviousness requirement to improve patent quality is the assumption that the agency should take a greater role in screening patent applications. This implicit assumption is embedded in the second, third, and fourth criteria for patent reform described above but is not justified by the NAS report. In asserting that both judicial and administrative decisions need to be reformed, the

319. See Lemley, supra note 139 , at 1508-11.

320. See id. at 1510; see also Joseph Scott Miller, Building a Better Bounty: Litigation-Stage Rewards for Defeating Patents, 19 BERKELEY TECH. L.J. 667 (2004).

321. See Ghosh \& Kesan, supra note 140.

322. See id. at 1248.

323. See id. at 1261. 
fourth criterion leaves ambiguous the proper relationship between judicial and administrative powers over the patent process. But only two of the seven recommendations apply to patent litigation: the strengthening of the experimental use defense and the removal of the doctrine of willful infringement. If all seven recommendations were fully implemented, patent prosecution, and hence the role of the PTO, would gain greater importance in the patent process and litigation would be more streamlined. The NAS report does not justify or even address its implicit, and seemingly extreme, assumption about the relative importance of the PTO and the courts. The assurance game supports this assumption by emphasizing the greater potential gains to certainty from creating a more open, multilateral process through reforming administration rather than litigation.

The assurance game teaches that the role of patent law is to ensure reciprocity and trust in the rules that regulate the innovation process. Administrative review has a greater potential for creating such reciprocity and trust than judicial review of patents. Through properly defined and administered rules, the PTO can resolve ex ante uncertainty over rights and produce a record of the prior art and inventiveness that is publicly open and reviewable. ${ }^{324}$ Judicial review, by contrast, resolves rights only after protracted litigation between two parties. ${ }^{325}$ While judicial review is a public process, litigation resolves uncertainty ex post, after the parties have presented the facts and an arbiter has determined the applicable law and applied it. For the kind of assurances needed in the innovation process, it makes sense to strengthen the prosecution process relative to the litigation process.

Furthermore, prosecution is potentially more open than litigation. The latter typically involves two parties and is only triggered when there is a dispute. The former is triggered upon application of a patent and involves the applicant and the agency. Under current rules, the patent prosecution process is not open. ${ }^{326}$ However, the presence of a government agent reviewing the process offers some basis for public review and oversight of the application. The public oversight offered by the government agent should not, of course, be exaggerated, but the final product of review is an open record that can be reviewed and that can serve as a basis for information available to all members of the public who are interested in a particular industry or technology. This public oversight of the prosecution process can be strengthened by implementing opposition and other review pro-

324. See NAS STUDY, supra note 15 , at 52-59.

325. See Ghosh \& Kesan, supra note 140 , at 1227-30.

326. See 35 U.S.C. $\$ 122$ (c) (2000). 
ceedings that allow interested parties to participate in the process. Needless to say, the administrative proceedings would increase the costs of patent prosecution, but these added up-front costs may prevent protracted infringement litigation. Since administrative processes have the potential of being more open and inclusive than litigation, the preference for administrative review is justified within the terms of the assurance game. ${ }^{327}$

But once reciprocity and trust are seen as the motivations for patents as a regulatory system, two problems become apparent in the NAS report. The first is the amount of deference granted to the findings of the PTO, specifically the question of the presumption of patent validity. The second is the relationship between patent law and competition policy. The report pays very little or no attention to each of these points, even though they are crucial to how we should understand patent reform.

The question of proper deference to the PTO is an ongoing controversy. In 1999, the Supreme Court held in Dickinson v. Zurko that the standards of the Administrative Procedure Act (APA) are applicable to judicial review of factual findings by the PTO. ${ }^{328}$ Contrary to some perceptions, the Court did not hold that the PTO was an agency under the APA, but assumed it, following the stipulation of the parties. ${ }^{329}$ Nonetheless, the application of the APA meant that at some level the courts had to accord the PTO some deference. Subsequent rulings by the Federal Circuit weakened this deference in two ways. The first was through judicial determination of what constituted an agency finding of fact, which requires deference, and an agency finding of law, which does not. ${ }^{330}$ In the remand from Zurko, for example, the Federal Circuit found that what was purported to be an agency finding of fact was really "official notice," the administrative equivalent of judicial notice, and therefore could be reviewed de novo in the nonobviousness determination. ${ }^{331}$ The second way that subsequent rulings weakened Zurko was by distinguishing between levels of deference. ${ }^{332}$ The Supreme Court rejected the clearly erroneous standard of review in Zurko, but was unclear as to whether the substantial evidence standard or the arbitrary and capricious standard, both recognized under the APA, was the appropriate alternative. ${ }^{333}$ The Federal Circuit ruled, after Zurko, that the less deferential substantial evidence standard was appli-

327. See supra notes $141-42$ and accompanying text.

328. 527 U.S. 150,152 (1999).

329. Id. at 154.

330. See Rai, supra note 139 , at 1056.

331. In re Zurko, 258 F.3d 1379, 1384-85 (Fed. Cir. 2001).

332. See Rai, supra note 139 , at 1056.

333. 258 F.3d at 1381. 
cable. ${ }^{334}$ The Zurko decision demonstrates that without proper consideration of the deference question, judicial review can undo a simple shift of authority from the courts to the PTO. The failure of the NAS report to address the issue, regardless of the resolution, is a major weakness.

The problem of deference is exacerbated by the problem of expertise. The presumption of deference for fact-finding in the APA rests on the assumption of agency expertise in the field of regulation. At the same time, the establishment of the Federal Circuit, an appellate court established to review appeals in patent cases, was based on the need for judicial expertise in the area of patents. Clearly, agency deference in the field of patents cannot be based solely on expertise, unless there is some basis for assuming that agencies are more expert than courts. Professor Orin Kerr finessed this question by arguing that the PTO is a different administrative agency from the public law agencies (such as the FTC or OSHA) to whom the APA was meant to apply. ${ }^{335}$ Since patent law is about private rights, no deference is mandated, he concludes. ${ }^{336}$ But the matter is not so simple. Patent law is regulatory in the sense that its goal is to regulate primary conduct. The regulatory goal is implemented through an agency, the PTO. Admittedly, the PTO has a different mission from other agencies, but as a functional matter, it carries out similar administrative tasks in reviewing applications and making decisions about grants and denials. If these ministerial tasks have any meaning, and are not meant to be simply undone or duplicated by courts, some degree of deference is due. The question is, how much? ?37 $^{33}$

The answer may rest on one specific area of deference that has been the focus of debate, and a specific focus of reform for the FTC: the presumption of validity of a patent. ${ }^{338}$ The current Patent Act expressly grants a presumption of validity to a granted patent in any judicial proceeding. ${ }^{339}$ This presumption, as the FTC report demonstrates, has been criticized for allowing invalid patents to survive judicial scrutiny and serve as the basis for anticompetitive patent litigation. ${ }^{340}$ As I discuss in section C, the presumption of validity is perhaps not the source of the problem. For addressing the problem of adequate deference, however, the presumption of pat-

334. In re Gartside, 203 F.3d 1305 (Fed. Cir. 2000).

335. See Kerr, supra note 131, at 129.

336. See id. at 134.

337. See Nard, supra note 131 , at 1421.

338. See FTC REPORT, supra note 16, Executive Summary.

339. See 35 U.S.C. $\$ 282(2000)$.

340. See Michael Meurer, Controlling Opportunistic and Anti-competitive Intellectual Property Litigation, 44 B.C. L. REV. 509, 527 (2003). 
ent validity provides a useful model. I propose that the PTO be granted deference but only for ministerial acts such as determining that an application is novel and nonobvious, given the prior art disclosed during patent prosecution. However, the court should give no deference to the scope of the prior art and should be allowed to review de novo the relevant prior art and the patentability of the invention given the expanded prior art. This proposed standard of deference differs from existing law in two ways. First, it is narrow, applying only to ministerial acts by the PTO. Second, it would apply to determinations of validity and invalidity equally. ${ }^{341}$

My proposed standard of deference would, if adopted in conjunction with the other proposals to make the prosecution process more open, aid to ensure the needed sense of reciprocity and trust necessary for patent reform. The proposed standard would also address the problems of anticompetitive patent litigation. While the NAS report does not directly address this issue, the 2003 FTC report does. In fact, the anticompetitive use of patents works to undermine the integrity of innovation markets as well as reciprocity and trust in the patent system. For these reasons, the FTC recommendations should be understood as complementary to those of the NAS. I address these additional recommendations in the next section.

\section{Patent Law and Competition Policy}

The previous two sections raised two points that I will further develop in this section. First, my regulatory theory of patent law would support a broad scope of patentable subject matter as well as a separation of the patentability decision from exercises of state police power for the purposes of improving public health, safety, and welfare. Second, patent reform, such as the recommendations from the NAS, should be guided by the need to support reciprocity and to generate trust both in the innovation process and the patent system. In this Section, I turn to the controversial question of the proper relationship between patent law and competition policy. I argue that the administration of patents should be guided by the goals of competition policy. This point is consistent with the argument of separation between patentability and the exercise of the police power because it applies to patent infringement and antitrust litigation. The point is also consistent with my emphasis on the values of reciprocity and trust, the recurring theme of this Article. Promoting reciprocity and trust and creating market

341. One criticism of the current standard is its asymmetric treatment of denials and grants of patents. The lack of presumption to a patent denial gives patent applicants two bites at the apple by permitting a challenge to a denial in court without the application of a presumption. See Burk \& Lemley, supra note 45 , at 1658-60. 
integrity require a recognition of the intimate relationship between patent law and competition policy.

In 2003, the FTC released a report entitled To Promote Innovation: The Proper Balance of Competition and Patent Law and Policy. ${ }^{342}$ The recommendations of the report overlap with and are complementary to those of the NAS report. While the NAS report presents seven insights into evaluating patent reform, the FTC report essentially has one: competitive markets are a key to innovation. ${ }^{343}$ To address this insight, the FTC presents ten recommendations for patent reform designed to better align patent policy and competition law. The recommendations; briefly, are:

1) Create post-grant review of and opposition to patents within the PTO;

2) Lower the standard for challenging patent validity by replacing a clear and convincing evidence standard with a preponderance of the evidence standard;

3) Raise the standards for nonobviousness by (i) tightening the commercial success test and (ii) evaluating inventions that are a combination of or modification to the prior art from the standards of creativity and problem-solving skills that are representative of those having ordinary skill in the art;

4) Adequately fund the PTO;

5) Implement internal reforms to the PTO that permit a more rigorous collection and review of prior art references;

6) Consider possible harm to competition before extending the proper scope of subject matter;

7) Require publication of all patent applications 18 months after filing;

8) Create intervening or prior user rights;

9) Require either actual written notice or actual knowledge for a claim of willful infringement;

10) Encourage the PTO and the Federal Circuit to consider economic learning and competition policy in patent law decision making. ${ }^{344}$

342. See FTC REPORT, supra note 16.

343. See id. ch. 1, at 7-9 (Chapter One: Introduction and Background).

344. See id. Executive Summary, at 10-17. 
While I agree with the FTC report in spirit, I am skeptical of some of the specific recommendations. Expanding the funding of the PTO, changing the standard of review for challenging validity, and limiting the scope of patentable subject matter each seem questionable. Since the PTO is one of the few government agencies to show a surplus through its activities and since the legislative impetus to appropriate this surplus keeps reappearing in each Congressional session, the funding of the PTO is arguably a compelling issue, particularly for addressing competition issues. The shift in the standard of review is a potential invitation for protracted and unnecessary litigation, while the narrowing of patentable subject matter is questionable for reasons given in Section A. However, the calls for an opposition proceeding, for intervening and prior user rights, and for reform of willful infringement are each promising. My goal here is not to critique each of the recommendations. Instead, I intend to show that the FTC's focus on the relationship between patent law and competition policy is important for developing a regulatory theory of patent law, consistent with the assurance game, and complementary to the goals of strengthening the role of the PTO, as the NAS recommends.

I emphasize again that I am not recommending that the two reports be implemented in their entirety. Instead, the two serve to illustrate my proposal for treating patent law as a system of regulation rather than as a system of protecting the right to exclude. My regulatory theory of patent law was used in Section B to develop a critique of certain elements of the NAS report, particularly its failure to address the question of deference. The theory can also be used to critique aspects of the FTC report, particularly the proposals to limit the presumption of validity and to limit the scope of patentable subject matter in light of competitive harms.

Weakening the presumption of validity raises the costs of patent infringement litigation and reduces the costs of patent challenges by licensees. ${ }^{345}$ A more appropriate solution would be to reform the standard for preliminary injunctions in patent law. ${ }^{346}$ This problem receives relatively little attention in the FTC report. Under current law, preliminary injunctions are a standard issue in patent litigation. While the standard for a preliminary injunction requires the district court to consider four factors (irreparable injury, likelihood of success on the merits, balancing of harms, and public interest), most jurisdictions focus exclusively on the first two

345. See id. at 8-10.

346. See Burk \& Lemley, supra note 45 , at 1658-60 (analyzing altering the presumption of validity); id. 1665-68 (analyzing the standards for preliminary injunctions). 
factors. ${ }^{347}$ Irreparable injury is typically shown by the validity of a patent, but weakening the presumption of validity will have little effect on the showing of irreparable injury since the court will scrutinize the record less closely in the preliminary injunction phase than in the trial phase. Weakening the presumption may have some effect in the court's analysis of likelihood of success on the merits. Once again, though, the court's scrutiny of the issue will not be as close as in the trial phase. The real problem, however, is that the court often fails to consider the harms faced by the defendant in a patent infringement suit either in terms of the balancing or in terms of the public interest. The concerns with the anticompetitive harms of patent law could more directly be dealt with if the court considered them in the decision to grant the preliminary injunction. Courts could do this readily by incorporating competition concerns both in the balancing and public interest prongs of the preliminary injunction analysis. For example, the anticompetitive implications of the one-click patent in the dispute between Amazon.com and Barnesandnoble.com could have been mitigated by a more stringent application of all four prongs of the preliminary injunction standard. Instead, the court, like many other courts, emphasized the first two elements without adequate consideration of the other elements in enjoining Barnesandnoble.com from using its version of oneclick shopping. ${ }^{348}$

The FTC report is also misguided in narrowing patentable subject matter on the grounds of potential competitive harms. ${ }^{349}$ While the Commission's chief target of this recommendation is business method patents, it is not clear that the recommendation would be, or even could be, limited to such patents. Within the spirit of the report, all patents are potentially anticompetitive in use, and therefore it is unclear that, in the extreme, many patents would survive such scrutiny. Furthermore, there is a compelling question of agency competence in gauging the anticompetitive implications of a particular patent grant. Agents lack not only the business and economic competence to assess these implications, but also the foresight to see all the possible uses of a given technology. Excluding anticompetitive inventions from patenting requires a consideration of the alternative: protection via trade secret or contract. To repeat the arguments made in

347. See, e.g., Tate Access Floors, Inc. v. Maxcess Techs., Inc., 222 F.3d 958, 971-72 (Fed. Cir. 2000).

348. See Amazon.com, Inc. v. Barnesandnoble.com, Inc., 73 F. Supp. 2d 1228, 124649 (W.D. Wash. 1999) (applying the four part preliminary injunction test, but emphasizing public interest in strong property rights in its analyses of the balancing of hardship and public interest prongs).

349. See FTC REPORT, supra note 16, Executive Summary, at 14-15. 
Section A, patent review and patenting provide sunlight to inventions, and it is perhaps better to have an invention that is patently anticompetitive, and hence readily subject to regulation, than an invention that works its anticompetitive harms in secrecy.

In making this recommendation, the FTC had in mind the patent misuse doctrine. ${ }^{350}$ Under this doctrine, a patent cannot be enforced against a particular party if the patent owner has exercised bad faith in the licensing or other use of the patent. This doctrine differs from the FTC recommendation in two ways. First, patent misuse doctrine is implemented by a court and not by the PTO. Second, patent misuse does not invalidate the patent but is rather an equitable defense to patent infringement. Nonetheless, the patent misuse doctrine is similar in spirit to the FTC recommendation. Both impose a powerful limit on the patent owner's rights based on improper use of the patent. The patent misuse doctrine is a more appropriate tool, however, because it does not suffer from the problems of narrowing patentable subject matter and because it directly targets anticompetitive behavior as it arises.

The doctrine of patent misuse has been controversial largely because it has been applied in an unpredictable manner and in situations that paralleled the improper use of antitrust laws against patent owners. But the FTC report demonstrates a reason for maintaining, and reforming, the patent misuse doctrine. Patents are used in an anticompetitive way. While antitrust law may address some of the problems, there may be uses that fall outside the types of market harms that antitrust law is designed to correct. Perhaps this is an argument for reforming antitrust law, but that, of course, would be beyond the scope of this Article. ${ }^{351}$ Absent broadreaching antitrust reform, judicious and appropriate treatment of patent misuse would provide the necessary remedy. ${ }^{352}$ Even a wholehearted critic of patent misuse like Judge Richard Posner has admitted recently about the need for the patent misuse doctrine in a recent copyright case. ${ }^{353}$

350. See Herbert Hovenkamp et. AL., IP AND Antitrust: An ANAlysis of AntITRUST PRINCIPLES APPLIEd TO INTEllectual Property LAW §§ 3.1-3.6 (Supp. 2004).

351. For an excellent discussion of the possibilities of patent misuse, see Robin $C$. Feldman, The Insufficiency of Antitrust Analysis for Patent Misuse, 55 HASTINGS L.J. 399, 405-09 (2003).

352. See, e.g., Robert J. Hoerner, The Decline (And Fall?) Of the Patent Misuse Doctrine in the Federal Circuit, 69 ANTITRUST L.J. 669 (2002) (providing a history of the patent misuse doctrine and discussing the possibility of strengthening the doctrine under current law).

353. See Assessment Tech. of WI, LLC v. WIREdata, Inc., 350 F.3d 640, 647 (7th Cir. 2003). 
In summary, the FTC report provides an important illustration of a regulatory system of patent law, one that does not rest on a fictional notion of social contract or on patents as property. Instead, a consideration of the relationship between patent law and competition policy indicates the possibility of analyzing patent law as a tool for regulating primary conduct. Finally, the FTC report shows how patent law can be designed to promote the goals of reciprocity and trust in the innovation process through addressing anticompetitive harms that threaten market integrity and beneficial uses of patents.

\section{AFTER THE PATENT BARGAIN METAPHOR: LESSONS FROM ELDRED}

The patent law community-practitioners, judges, and scholars - often refer to patents as part of a bargain or a quid pro quo. The pervasiveness of this metaphor, and its potential danger, were made apparent by the majority decision in Eldred, which relied on the patent bargain to interpret the bargain struck under copyright. The metaphor is not only unhelpful and indeterminate but also misleading. Representing patents descriptively and normatively as bargains relies on misguided political and economic theory. This Article is a call to the patent law community to reform the social contract in both senses of the word. First, the social contract should be reformulated to take into consideration modern theories of law and regulation as well as the importance of reciprocity and trust in the innovation process. Second, this reformulation of patent law as a system of regulation allows us to understand how to improve the system through better institutional design of agencies and courts and through coordination with the law of competition.

To think of patent law as a form of regulation enriches our discussion by moving beyond the conception of patents as property and of patent law as a means for defining title and ownership. The reformulation as regulation makes it possible to more accurately and completely debate reform of the institutions and practices of patent prosecution and litigation. It also allows us to understand the relationship between patent law and other regulatory systems such as the law of unfair competition, antitrust, and food and drug law. For those wedded to the quid pro quo metaphor, the retreat from property may be unwelcome because it leads to the narrowing of patent law and of the role of patent practitioners, with attendant loss in market growth and professional position. But, as my discussion of patentable subject matter indicates, the regulatory theory of patent supports broad subject matter because the patent process can make the innovation 
process more open and subject to scrutiny. For these same practitioners, "regulation" may be a code word for limiting and curtailing activity. But as the assurance game shows, patent law as regulation is aimed at promoting innovation by fostering an environment that encourages reciprocity, trust, and the integrity of the marketplace. Just as securities regulation is designed to promote investment in securities markets, so too should regulatory patent law should be designed to promote trust in the process of innovation in new technologies. To reformulate the social contract description of patents is to replace an indeterminate and vague metaphor with a more coherent view of patents that is better suited to the task of promoting the innovation and dissemination of valuable technologies.

Since I started this Article with a reference to the Eldred decision, one may ask whether my discussion helps in understanding Eldred. The pessimistic answer is that by identifying the bargain metaphor as a conceptual problem, I have suggested that the outcome upholding the Copyright Term Extension Act was perhaps inevitable. But a more optimistic answer is implied for future cases like Eldred. By thinking of patent law, and intellectual property more broadly, as regulatory, and by retreating from the pernicious and misguided metaphor of the quid pro quo, we can imagine richer arguments, based on an appreciation of the primary conduct that intellectual property law regulates. These arguments could help courts to understand both the statutory and constitutional dimensions of intellectual property. This difficult and important task can be completed by questioning the patent bargain metaphor and reforming the social contract through the lens of regulation. 